\title{
Recent Developments in Luffa Natural Fiber Composites: Review
}

\author{
Mohamad Alhijazi ${ }^{1}$, Babak Safaei ${ }^{1, *} \mathbb{0}$, Qasim Zeeshan ${ }^{1} @$, Mohammed Asmael ${ }^{1} \oplus$, \\ Arameh Eyvazian ${ }^{2,3}$ and Zhaoye Qin ${ }^{4, *}$ \\ 1 Department of Mechanical Engineering, Eastern Mediterranean University, Famagusta 99628, North Cyprus \\ via Mersin 10, Turkey; mohamadalhijazi@gmail.com (M.A.); qasim.zeeshan@emu.edu.tr (Q.Z.); \\ mohammed.asmael@emu.edu.tr (M.A.) \\ 2 Institute of Research and Development, Duy Tan University, Da Nang 550000, Vietnam; \\ arameheyvazian@duytan.edu.vn \\ 3 Faculty of Electrical-Electronic Engineering, Duy Tan University, Da Nang 550000, Vietnam \\ 4 Department of Mechanical Engineering, Tsinghua University, Beijing 100084, China \\ * Correspondence: babak.safaei@emu.edu.tr (B.S.); qinzy@mail.tsinghua.edu.cn (Z.Q.)
}

Received: 11 August 2020; Accepted: 11 September 2020; Published: 17 September 2020

\begin{abstract}
Natural fiber composites (NFCs) are an evolving area in polymer sciences. Fibers extracted from natural sources hold a wide set of advantages such as negligible cost, significant mechanical characteristics, low density, high strength-to-weight ratio, environmental friendliness, recyclability, etc. Luffa cylindrica, also termed luffa gourd or luffa sponge, is a natural fiber that has a solid potential to replace synthetic fibers in composite materials in diverse applications like vibration isolation, sound absorption, packaging, etc. Recently, many researches have involved luffa fibers as a reinforcement in the development of NFC, aiming to investigate their performance in selected matrices as well as the behavior of the end NFC. This paper presents a review on recent developments in luffa natural fiber composites. Physical, morphological, mechanical, thermal, electrical, and acoustic properties of luffa NFCs are investigated, categorized, and compared, taking into consideration selected matrices as well as the size, volume fraction, and treatments of fibers. Although luffa natural fiber composites have revealed promising properties, the addition of these natural fibers increases water absorption. Moreover, chemical treatments with different agents such as sodium hydroxide $(\mathrm{NaOH})$ and benzoyl can remarkably enhance the surface area of luffa fibers, remove undesirable impurities, and reduce water uptake, thereby improving their overall characteristics. Hybridization of luffa NFC with other natural or synthetic fibers, e.g., glass, carbon, ceramic, flax, jute, etc., can enhance the properties of the end composite material. However, luffa fibers have exhibited a profuse compatibility with epoxy matrix.
\end{abstract}

Keywords: luffa natural fiber composites; mechanical properties; physical properties; thermal properties; chemical properties; morphological properties

\section{Introduction}

Fiber-reinforced composites are becoming significantly popular in various engineering fields due to their low density as well as their remarkable mechanical characteristics. Composite materials' properties are based on the selected components, viz., matrix and fibers [1-3]. Hitherto, the utilized matrices and fibers are generally obtained from petroleum origins. Although they possess attractive properties, the aforementioned composite materials are restricted from being used for long periods, yet can endure regular environmental conditions for tens of years [4-9]. Moreover, composite recycling and reprocessing methods are unavailable. The manufacturing of most synthetic fibers has several 
environmental effects, as it requires high power, is toxic for humans, as well as may deplete the ozone layer, cause global warming and eutrophication [10-13]. The increased attentiveness to environmental matters has augmented the search for an alternative natural source in order to increase the utilization of renewable materials, reduce waste production, boost recycling, and so on $[14,15]$.

Hence, numerous scientists and engineers tend toward green materials that can enhance the products' environmental aspects [13,16-19]. Thus, materials extracted from natural resources gained more attention as an alternative to synthetic fibers in composite materials. Natural fibers (NFs) are found in many parts of a plant, e.g., fruit, bast, leaf, trunk, roots, and so on. Throughout the decades, these natural fibers have been widely utilized in countless applications due to their advantages, as they are strong, lightweight, tough, recyclable, biodegradable, abundant in nature, and have negligible cost and low density [20-27]. Additionally, their environmental advantages include decreased respiratory and dermal irritation, improved energy consumption, less wear and abrasion on tools, and minimal health hazards. Natural fiber composites (NFCs) have been significantly involved in various engineering fields such as automotive, marine, sports gear, construction, and aerospace $[17,28-34]$.

NFs, also named lignocellulosic fibers, comprise wheat straw, sea grass, softwood kraft, sisal, rice husk, ramie, rachis, pineapple, oil palm, date palm, jute, hemp, flax, coconut, coir, cotton, banana, bamboo, abaca, mesta, roselle, oat, maize, sabia, kapok, etc. [35-43]. Figure 1 shows the main fiber categories. Besides the prosperous characteristics of natural fibers, they have a few disadvantages due to their hydrophilic behavior. However, there are several methods that can reduce these drawbacks, like adding coupling agents and fiber treatment. Luffa fruit comprise lightweight natural fibers that have the potential to be utilized in reinforcing lightweight composites due to their polyporous structure, abundance, cheap price, as well as their surface morphology, which can provide a good adhesion with the matrix. The main focus of this review paper is to compile, compare, and summarize the research on luffa natural fiber composites (LNFCs) by considering the physical, morphological, mechanical, chemical, electrical, and thermal properties, in addition to acoustic, water absorption, x-ray diffraction, differential scanning calorimetric, thickness swelling, and so on.

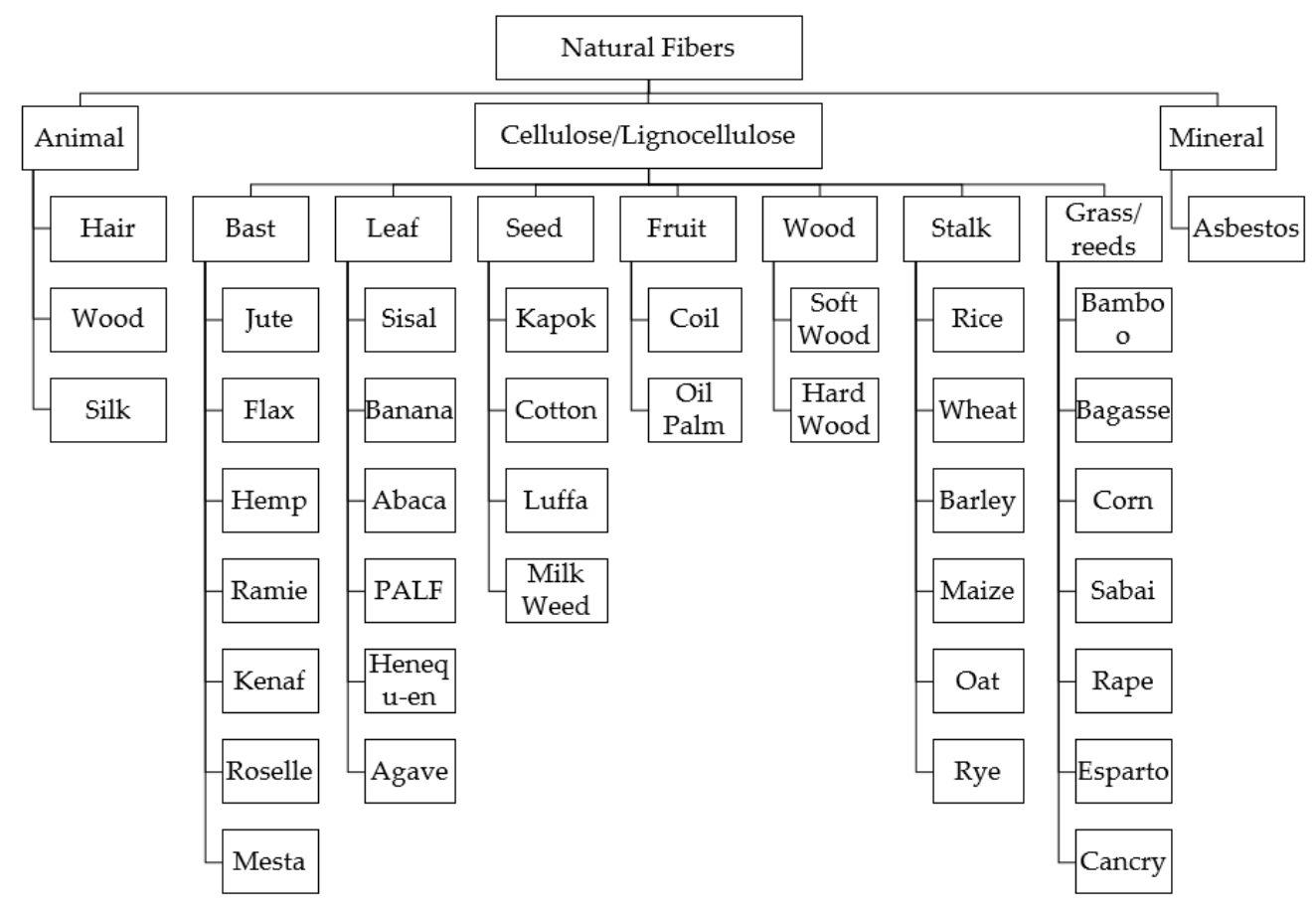

Figure 1. General classifications of natural fibers. 


\section{Luffa and Its Composite Materials}

Luffa is a category of the Cucurbitaceae family (cucumber), its ripe fruits are utilized as natural cleaning sponges, while its immature fruits are consumed as vegetables. It is spread from south Asia to east and central Asia. Luffa vegetables are widespread in Vietnam and China. Figure 2 shows the mature luffa fruit and its fiber structure. Luffa fibers comprise significant toughness, strength, and stiffness, similar to the ones observed in various metals with same density ranges [44].

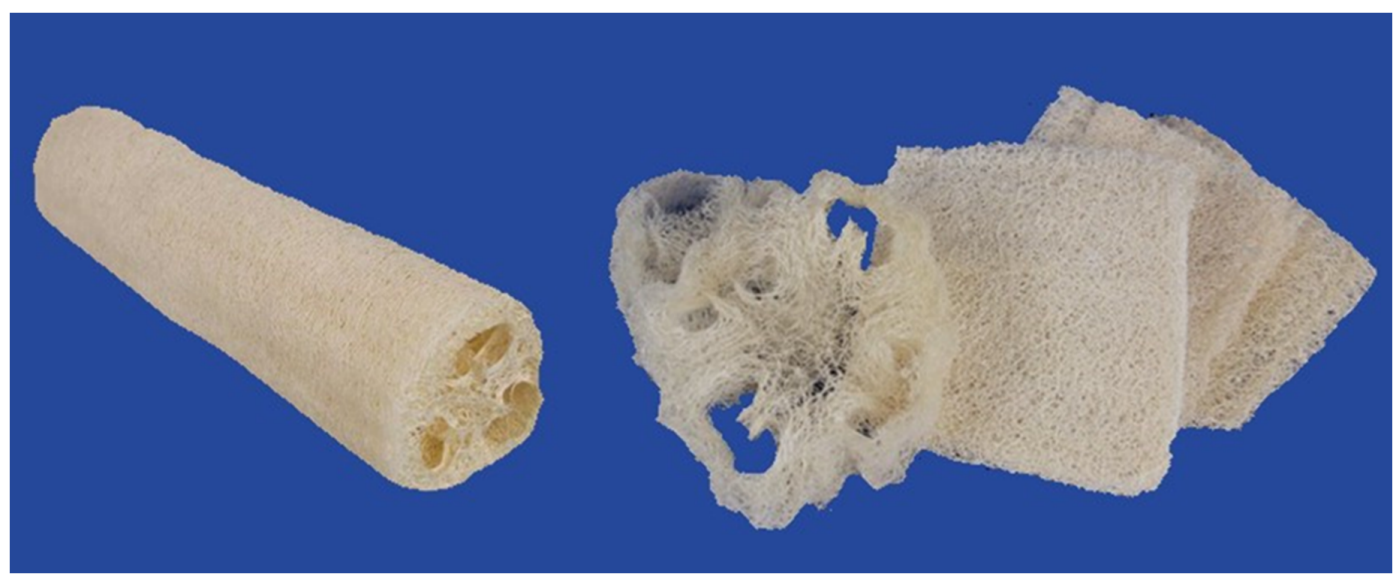

Figure 2. Luffa and its internal structure.

Luffa chemical composition mostly consists of lignin and hemicellulose/cellulose, as well as includes some inorganic elements like glycosides, polypeptides, amino acids, proteins, and so on [45-47]. However, the hemicellulose content ranges between $8 \%$ and $22 \%$, lignin content is between $10 \%$ and $23 \%$, and cellulose content is between $55 \%$ and $90 \%$. Table 1 shows the physical and chemical properties of luffa. At the early stage of luffa growth, its cellular structure begins with numerous single fibers and turn into fibrous mat at the end [48].

Table 1. Physical properties and chemical composition of luffa fibers [49-51].

\begin{tabular}{cccccccc}
\hline \multicolumn{3}{c}{ Physical Properties } & \multicolumn{5}{c}{ Chemical Composition } \\
\hline $\begin{array}{c}\text { Density } \\
\left(\mathrm{gm} / \mathrm{cm}^{3}\right)\end{array}$ & $\begin{array}{c}\text { Diameter } \\
(\mu \mathrm{m})\end{array}$ & $\begin{array}{c}\text { Aspect } \\
\text { ratio }\end{array}$ & $\begin{array}{c}\text { Micro } \\
\text { fibrillar } \\
\text { angle }\left({ }^{\circ}\right)\end{array}$ & $\begin{array}{c}\text { Cellulose } \\
(\%)\end{array}$ & $\begin{array}{c}\text { Lignin } \\
(\%)\end{array}$ & $\begin{array}{c}\text { Hemi } \\
\text { cellulose } \\
(\%)\end{array}$ & Ash $(\%)$ \\
$0.56-0.92$ & $270 \pm 20$ & $340 \pm 5$ & $12 \pm 2$ & $63.0 \pm 2.5$ & $11.69 \pm 1.2$ & $20.88 \pm 1.4$ & $0.4 \pm 0.10$ \\
\hline
\end{tabular}

As Table 1 shows, luffa density varies from 0.56 to $0.92 \mathrm{~g} / \mathrm{cm}^{3}$, it has an average diameter of $\sim 270 \mu \mathrm{m}$, and its microfibrillar angle is around $12^{\circ}$. The chemical composition of luffa consists of $63 \%$ cellulose, $20.88 \%$ hemicellulose, $11.69 \%$ lignin, and $0.4 \%$ ash. It is worth mentioning that in addition to its use as a vegetable and cleaning sponge, luffa is also utilized in Chinese medication, military filters, and shock absorbers [52].

\subsection{Fiber Treatment}

Water absorption and moisture retention harm the fiber/matrix adhesion in composite materials. Moreover, NFs have high moisture absorption properties as they are naturally hydrophilic. Such properties cause a reduction in bond strength, and thus matrix and fibers detach from each other. Hence, these composite materials exhibit negligible mechanical characteristics in wet environments [53]. Therefore, treating an NF with a convenient chemical solution can influence its chemical composition, remove surface impurities, as well as reduce its water absorption character. Table 2 shows the treatments applied to luffa fibers in LNFC studies. 
Table 2. Luffa fiber treatments.

\begin{tabular}{cc}
\hline Treatment & Reference \\
\hline Sodium Hydroxide $(\mathrm{NaOH})$ & {$[25,44,49-51,54-76]$} \\
\hline Hydrogen Peroxide $\left(\mathrm{H}_{2} \mathrm{O}_{2}\right)$ & {$[27,54,55,65-67]$} \\
\hline Acetic Acid $\left(\mathrm{CH}_{3} \mathrm{COOH}\right)$ & {$[27,54,55]$} \\
\hline Carbamide $\mathrm{CO}\left(\mathrm{NH}_{2}\right)$ & {$[55]$} \\
\hline Methacrylamide & {$[60,69]$} \\
\hline Benzoyl Chloride Permanganate $\left(\mathrm{KMnO}_{4}\right)$ & {$[51,75]$} \\
\hline Acetic Anhydride, and Acetone & {$[65]$} \\
\hline Furfuryl Alcohol followed by oxidation $($ sodium & {$[50]$} \\
\hline chlorite + acetic acid) & {$[57]$} \\
\hline CaCl ${ }_{2}, \mathrm{H}_{2} \mathrm{SO}_{4}$, and Na $\mathrm{HPO}_{4}$ & {$[58]$} \\
\hline Hypochlorite (NaClO) & {$[64]$} \\
\hline Ethanol, BTDA Dianhydrides & {$[56]$} \\
\hline HCl & {$[46,77]$} \\
\hline $\mathrm{Chlorine} \mathrm{Bleach}$ & {$[78]$} \\
\hline CalciumPhosphate and Calcium Carbonate & {$[71]$} \\
\hline CaOH ${ }_{2}$ and Silane & {$[79]$} \\
\hline $\begin{array}{c}\text { Thermo-mechanical treatment and } \\
\text { thermo-hydromechanical treatment }\end{array}$ & {$[80]$} \\
\hline Heat treatment &
\end{tabular}

Sodium hydroxide $(\mathrm{NaOH}) /$ alkaline treatment evidenced its capability in improving luffa fibers' microstructure by changing its chemical composition as well as removing all impurities [49,59-63,70]. Treating luffa fibers with $4 \% \mathrm{NaOH}$ at $120^{\circ} \mathrm{C}$ for $3 \mathrm{~h}$ revealed the highest fiber crystallinity index and, in addition, combined chemical treatments switched luffa from a mat into a filament structure [67]. Contrary to other chemical solutions, methacrylamide treatment caused a serious deterioration in luffa fiber integrity [69]. Mixing $\mathrm{NaOH}$ with other solutions like $\mathrm{CH}_{3} \mathrm{COOH}$ can drastically improve LNFC mechanical performance as well as significantly decrease its water absorption; in contrast, mixing with $\mathrm{H}_{2} \mathrm{O}_{2}$ deteriorated its mechanical characteristics [55]. The tensile strength of LNFC created with $\mathrm{HCl}$ treated fibers was lower than that of LNFC treated with alkaline [56]. Cyanoethylating and acetylation improved fiber/matrix adhesion, resulting in an enhancement in mechanical characteristics $[65,66]$. Furfuryl alcohol followed by oxidation treatment revealed higher performance compared to alkaline, where it improved the surface structure and reduced hemicellulose, lignin, and wax quantities [50]. As shown in Table 2, sodium hydroxide was mostly utilized to chemically treat luffa fibers, followed by hydrogen peroxide and acetic acid.

\subsection{Matrices Selected for LNFCS}

Composites have a combination of fibers and matrix properties, and in addition to matrix properties, they behave as a structure that holds all fibers together, as well as a protection from the surrounding environment (water, heat, etc.) [1,81-83]. Thus, studying the performance of a new NFC involves choosing a suitable matrix that exhibits good properties with a considerable interaction with the selected NF. Several studies investigated luffa as a pure mat (without a matrix); however, others studied different thermoplastics and thermosets like epoxy, polyester, resorcinol-formaldehyde, vinyl ester, and so on [84-86]. Matrices considered in recent LNFC studies are listed in Table 3. 
Table 3. Thermoplastics and thermosets used in luffa natural fiber composite (LNFC) development.

\begin{tabular}{cc}
\hline Matrix & Reference \\
\hline Epoxy & {$[25,44,49-51,54,59,61-63,72-75,84,87-93]$} \\
Polyester & {$[24,56,60,65,66,70,71,84,94-96]$} \\
Resorcinol-formaldehyde & {$[57,78,97]$} \\
Polylactic acid & {$[58,80]$} \\
Bio-based polyethylene (HDPE) & {$[98]$} \\
Vinyl ester & {$[7,64]$} \\
Polyurethane foam & {$[45]$} \\
Polyurethane (PU) & {$[99]$} \\
Polypropylene & {$[68]$} \\
Geopolymer & {$[100]$} \\
Pre-gelatinized cassava starch & {$[101]$} \\
Eva resin & {$[102]$} \\
Bismuth nitrate pentahydrate $\left(\mathrm{Bi}\left(\mathrm{NO}_{3}\right)_{3} \cdot 5 \mathrm{H}_{2} \mathrm{O}\right)$ and & {$[76]$} \\
potassium iodide & {$[103]$} \\
Concrete &
\end{tabular}

LNFC studies have involved diverse polymeric matrices with different weight ratios (fiber volume fraction), which ranged from $2 \mathrm{wt} . \%$ to $50 \mathrm{wt} . \%$, however, the most common weight composition was 30 wt. $\%$ [24,49,50,62,70]. Although the majority of studies considered luffa as rectangular mat, some utilized it as randomly chopped fibers between $2 \mathrm{~mm}$ and $6 \mathrm{~cm}$. As clearly shown in Table 3, epoxy resin was selected most often in the LNFC area, followed by polyester and resorcinol-formaldehyde, which is due to matrix properties as well as matrix/fiber compatibility.

\section{Characteristics of LNFCs}

The characteristics of a natural fiber composite are essential for ensuring its appropriateness for being implemented in industrial sectors [104-107]. These include mechanical properties such as tensile strength, flexural strength, impact, compression, hardness, etc., and physical properties like water absorption, density, and so on, taking into account its behavior towards chemical solutions and thermal changes $[40,43,108]$. This section includes a summary and comparison of findings revealed in published LNFC researches.

\subsection{Morphology of LNFCs}

One of the most important factors in NFC development is studying its microstructure in order to determine its fracture type, fiber surface morphology (especially to figure out the effect of a treatment), crystallinity index, and so on. Moreover, studying the morphology of an LNFC identifies the degree of compatibility of these fibers with the selected matrix, and thereby specifies the condition of fiber-to-matrix adhesion and manifests the internal flaws. Usually, morphological analyses are conducted on the fracture surface of a failed LNFC specimen, which helps to define the failure nature (brittle or ductile). Scanning electron microscopy (SEM), transmission electron microscopy, polarized light microscopy, X-ray diffraction [109] and other tests were utilized in several studies to analyze the morphology of luffa mat/fiber and LNFC [109-114].

\subsubsection{Microscopy}

Diverse microscopic techniques have been used for luffa fibers and LNFCs, such as polarized light microscopy (PLM), scanning electron microscopy (SEM), field emission scanning electron microscopy (FESEM), optical microscopy, etc. However, researches have considered scanning electron microscopy most often for inspecting the fiber surface morphology, voids presence, fiber/matrix interaction, and so on. Few researches scanned pure luffa samples [55,67,69], while others involved the following matrices: epoxy $[44,50,51,59,61-63,89,91]$, polyester $[60,66,96]$, polypropylene [68], vinyl ester [64], 
geopolymer [100], pre-gelatinized cassava starch [101]. SEM micrographs of untreated and treated fibers are shown in Figures 3 and 4; FESEM micrographs of treated luffa/epoxy are illustrated in Figure 5.

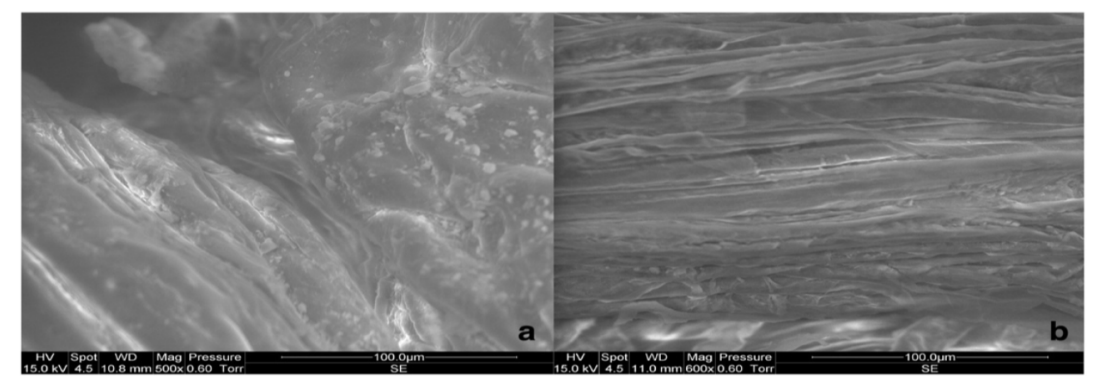

Figure 3. SEM micrographs of (a) untreated luffa fibers; (b) alkali-treated luffa fibers. Adapted with permission from ref. [67]. Copyright 2020, Elsevier.

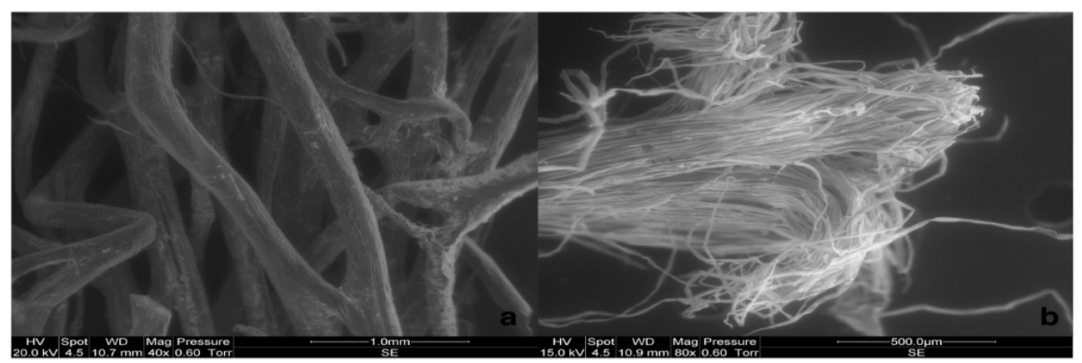

Figure 4. SEM micrographs of (a) morphology of untreated luffa fibers; (b) fibrillary structure of treated fibers. Adapted with permission from ref. [67]. Copyright 2020, Elsevier.

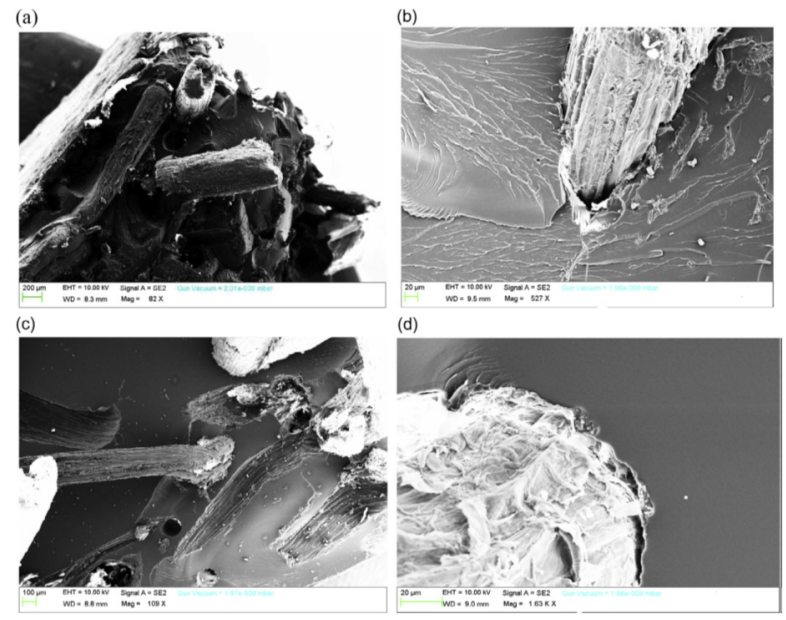

Figure 5. Field emission SEM of treated luffa/epoxy NFC (a) Fracture surface of short fibers LNFC (82×), (b) Luffa fiber cracked side (527×), (c) fracture surface of mat LNFC (100×) and (d) Luffa fiber cracked side $(100 \mathrm{k} \times)$. Adapted with permission from ref. [59]. Copyright 2020, Elsevier.

SEM contributes to showing the fibers' surface roughness as well as their fibrous structure. Normally, the outer surface of lignocellulosic fibers consists of a waxy and fatty layer with salt-like solids. Luffa fibers have a flake-like structure and are highly capable of enduring tensile forces. Selecting these fibers as a reinforcement can enhance the composite's strength [44]. Extraction treatment reduced the amount of solids covering the fibers' surface by decreasing the roughness rate [64]. From SEM micrographs, Anbukarasi et al. [59] observed that particle fibers and short fibers had a promising behavior in LNFC. In addition, considering luffa as a mat contributes to restricting the fibers from 
pulling out from the matrix due to its network structure, which thereby improved the mechanical properties such as tensile strength, flexural, impact, etc. [62]. Chemically treating luffa fibers reduced the hydroxyl groups' number as well as increased the fibers' surface roughness [83]. Hence, fiber treatment improved their bonding with the matrix and reduced the voids content $[68,115,116]$.

\subsubsection{X-ray Diffraction}

Generally, an X-ray diffraction test (XRD) helps in evaluating the crystallographic nature of natural fiber composites like LNFC, as well as determining the impact of chemical treatments on the crystalline nature. Recent research implemented XRD to study LNFCs with an epoxy matrix [51], polyester matrix [65,66,96], resorcinol-formaldehyde [57,78], geopolymer [100], polylactic acid [58], and pure luffa fibers $[27,55,67,69]$.

LNFC cell walls contain mainly lignin, hemicellulose, and cellulose. Hemicellulose and lignin are amorphous, while cellulose includes crystalline as well as amorphous phases [51]. Almost all researches obtained maximum crystallinity values in a range between $20^{\circ}$ and $25^{\circ}$ of 2-Theta, while the amorphous peaks were exhibited between $14^{\circ}$ and $16^{\circ}$ [51]. By increasing the fiber volume fraction in LNFC, the crystallite size and crystallinity decreased, which evidenced a remarkable bone bonding as well as bone implant [78]. Chemically treating luffa fibers increased the cellulose crystallinity index (a value of around 60\%), which can result in a simultaneous increase in that of the end LNFC [57]. Various chemical treatments were able to improve the crystallinity index of luffa fibers and showed a range of values from $59 \%$ to $63 \%$ [69].

\subsection{Physical Properties}

Developing a new natural fiber composite like LNFC is critical in terms of its physical characteristics $[117,118]$; for example, its density should be compared with materials from the same category, its thickness swelling has to be inspected in order to define its dimensional stability, and most importantly, as a natural fiber composite, its water absorption must be examined since it may lead to a drastic property degradation. Since NFCs are being utilized in the industry for sound insulation purposes, the acoustic behavior of luffa fibers is high in importance, as well $[119,120]$.

\subsubsection{Density}

Basically, the density of LNFC is measured by weighing the cured samples and measuring their dimensions, then dividing the obtained mass by volume. Densities of LNFCs with various matrices are listed in Table 4.

Table 4. Density of luffa natural fiber composites.

\begin{tabular}{|c|c|c|c|c|c|c|}
\hline $\begin{array}{l}\text { Resin/Coupling } \\
\text { Agent/Hardener }\end{array}$ & $\begin{array}{c}\text { Fiber } \\
\text { Treatment }\end{array}$ & Fiber Size/Shape & $\begin{array}{c}\text { Fiber } \\
\text { Composition } \\
\text { Vf/wt. } \%\end{array}$ & Hybrid/Filler & Density $\mathrm{g} / \mathrm{cm}^{3}$ & Reference \\
\hline Epoxy/Hardener HY951 & & Rectangular mat & $19.87-30.86 \% \mathrm{Vf}$ & Glass fiber & $1.009-1.297$ & [91] \\
\hline Epoxy/hardener K-6 & $\mathrm{NaOH}$ & $2-5 \mathrm{~mm}$ & $3.2-9.6 \mathrm{wt} . \%$ & & $1.1142-1.1501$ & [25] \\
\hline Formaldehyde & & $\begin{array}{l}\text { Mat in medium } \\
\text { density fireboard }\end{array}$ & & $\begin{array}{l}\text { Pine, beech, } \\
\text { and oak }\end{array}$ & $0.717-0.721$ & [97] \\
\hline $\begin{array}{c}\text { Geopolymer } \\
\text { (metakaolin activated } \\
\text { with sodium silicate } \\
\text { and sodium hydroxide } \\
\text { solutions) }\end{array}$ & & $\begin{array}{l}\text { Fiber's D: } 200 \mu \mathrm{m} . \\
\text { L: } 160 \mathrm{~mm}\end{array}$ & 10 vol. $\%$ & & 1.38 & [100] \\
\hline
\end{tabular}

The density of LNFCs range between 0.7 and 1.38, depending the selected matrix (as shown in Table 4). Besides the notable improvement in the mechanical properties of SK-geopolymer after the addition of luffa fibers as a reinforcement, the end composite material revealed a $1.38 \mathrm{~g} / \mathrm{cm}^{3}$ density lower than that of pure geopolymer $\left(1.5 \mathrm{~g} / \mathrm{cm}^{3}\right)$ [100]. Regarding LNFC with an epoxy matrix, increasing the fiber volume fraction by up to $9.6 \%$ decreased the overall density by $3.12 \%$ [25]. Average 
density of luffa/formaldehyde NFC ranges between 0.719 to $0.721 \mathrm{~g} / \mathrm{m}^{3}$; however, the density of this NFC decreased by increasing fiber content [97]. Moreover, the observed density reduction emphasized the light weight of LNFC.

\subsubsection{Water Absorption}

Water absorption is one of the main concerns in utilizing NFCs in several areas. This property is usually tested by immersing NFC specimens in distilled water for a period of time at room temperature, then removing the specimens and wiping the remaining water droplets from their surfaces [121,122]. Hence, the weight of these samples is measured and compared with their initial weight in order to calculate the weight change ratio [123,124]. Water absorption property was tested for LNFCs with several matrices such as: epoxy $[49,50,59,62,63]$, polyester $[24,60,66,95]$, polypropylene [68], vinyl ester [64], polylactic acid [80], pre-gelatinized cassava starch [101], as well as pure luffa bundles [27,55]. Since luffa fibers are hydrophilic in nature, their addition into a matrix increased the overall water absorption of the NFC due to the existence of homocellulose and pectin. Therefore, water absorption of LNFC increased by increasing the fiber volume fraction [49]. Furthermore, LNFC with treated as well as untreated fibers showed a quick weight increase in the first week of its immersion in water. Yet the water turned blurry, which indicated that the polymeric matrix was losing some of its components [60]. However, untreated LNFC exhibited around $14 \%$ higher water uptake, compared to treated LNFC, which indicated that the latter had a better compatibility with the matrix $[59,63]$. Additionally, void content and density of the material significantly affected its water absorption [24].

\subsubsection{Thickness Swelling}

Thickness swelling is a critical property in natural fiber composites, it describes the dimensional stability of these composites after absorbing moisture. However, the swelling rate is low throughout the early moisture absorption stages of a natural fiber composite made with polymeric matrix, due to the viscoelastic behavior of this polymer. Hence, reaching a high swelling rate leads to the deterioration of the mechanical properties such as tensile strength, compression, impact, bending, etc. To date, research on thickness swelling of LNFC is still limited. Akgül et al. [97] observed that the thickness swelling of luffa/formaldehyde NFC increased by increasing luffa layers in the sample, whereas samples with three luffa layers exhibited peak thickness swelling percentage.

\subsubsection{Acoustic Resistance}

Enhancing the environmentally friendly composites, LNFCs have a solid potential to be involved in several vibration and sound isolation utilizations, such as in yachts, cars, and airplanes, due to their high elastic properties and damping [89,125-129]. Pure luffa fibers have a significant sound absorption coefficient, which indicates that thick, pure luffa specimens can result in better acoustic properties [87]. The addition of luffa fibers into a polymeric matrix caused it to exhibit profusely high acoustic properties in the end NFC at all frequencies, since it improved the soundproofing to four times higher at moderate frequency levels [45]. Saygili et al. [130] observed that the damping level of luffa/epoxy was higher than that of jute/epoxy natural fiber composite. Furthermore, Genc et al. [89] concluded that the acoustic properties of LNFCs with an epoxy matrix were significantly promising, which can allow them to be involved in practical usages, while Shen et al. [77] recommended the utilization of LNFCs for sound absorption and vibration applications.

\subsection{Mechanical Properties}

Mechanical characteristics of an NFC are specified through multiple tests, like hardness, flexural, tensile, compression, impact, etc. [131,132]. The mechanical properties of LNFCs are summarized and discussed in this section. Mechanical testing results obtained in recent LNFC studies are compiled and classified in Table 5, all the listed tests were conducted following the standard of American society for testing materials (ASTM). 
Table 5. Mechanical properties of luffa natural fiber composites.

\begin{tabular}{|c|c|c|c|c|c|c|c|c|c|}
\hline $\begin{array}{c}\text { Resin/Fiber } \\
\text { Treatment }\end{array}$ & $\begin{array}{l}\text { Fiber Size, Shape, and } \\
\text { Composition Vf/wt.\% }\end{array}$ & Hybrid/Filler & $\begin{array}{l}\text { Tensile } \\
\text { (MPa) }\end{array}$ & Flexural (MPa) & $\begin{array}{l}\text { Compression } \\
\text { (MPa) }\end{array}$ & Impact & Hardness & Other & Ref. \\
\hline Epoxy/NaOH & $\begin{array}{c}\text { Particles, short fibers, and } \\
\text { mat shaped fibers } \\
(0.3-0.5 \mathrm{Vf})\end{array}$ & & 23 & 115 & 107 & $27 \mathrm{KJ} / \mathrm{m}^{2}$ & & & [59] \\
\hline Epoxy/NaOH & $\begin{array}{c}10-20 \mathrm{~mm} \\
(10 \%, 20 \%, 30 \%, 40 \% \text { and } \\
50 \% \mathrm{Vf})\end{array}$ & $\begin{array}{l}\text { Ground nut } \\
\qquad(1: 1)\end{array}$ & 20 & 72 & 52.22 & $1.3 \mathrm{~J}$ & & & [62] \\
\hline Epoxy/NaOH & $\begin{array}{c}\text { Mat } \\
(30 \% \text { Vf })\end{array}$ & Flax & 24 & 59 & & $1.9 \mathrm{~J}$ & & & [49] \\
\hline Epoxy/NaOH & & $\begin{array}{c}\text { Ceramic } \mathrm{B}_{4} \mathrm{C}(10 \\
\text { wt. } \%)\end{array}$ & $\begin{array}{c}13.56 \\
\text { E: } 73.29\end{array}$ & & 34.39 & $18000 \mathrm{~J}$ & $91 \mathrm{HRc}$ & & [44] \\
\hline Epoxy & $\begin{array}{c}\text { Rectangular mat } \\
(8,13 \text { and } 19 \text { wt. } \%)\end{array}$ & & $\begin{array}{c}18 \\
\text { E: } 699\end{array}$ & 28 & & $4.90 \mathrm{KJ} / \mathrm{m}^{2}$ & $\begin{array}{c}217.20 \\
\mathrm{MPa}\end{array}$ & $\begin{array}{c}\text { Interlaminar } \\
\text { shear stress } \\
\text { (ILSS): } 1.38 \\
\text { MPa } \\
\text { Erosion: } 45 \% \\
\text { to } 60 \% \text { IA }\end{array}$ & [90] \\
\hline Epoxy & $\begin{array}{l}\text { Rectangular mat } \\
(19.87-30.86 \% \text { Vf) }\end{array}$ & Glass fiber & 35.34 & 108.36 & & & $53.825 \mathrm{Hv}$ & $\begin{array}{c}\text { ILSS: } 5.628 \\
\mathrm{MPa}\end{array}$ & [91] \\
\hline $\begin{array}{l}\text { Epoxy/ } \mathrm{NaOH} \text {, and } \\
\text { furfuryl alcohol } \\
\text { followed by } \\
\text { oxidation (sodium } \\
\text { chlorite }+ \text { acetic } \\
\text { acid) }\end{array}$ & $\begin{array}{l}100 \times 100 \text { mat } \\
(30 \text { wt. } \%)\end{array}$ & & $\begin{array}{c}226.40 \\
\text { E: } 5865.70\end{array}$ & & & $7 \mathrm{KJ} / \mathrm{m}^{2}$ & & & {$[50]$} \\
\hline $\begin{array}{c}\text { Epoxy/NaOH, } \\
\text { benzoyl chloride, } \\
\text { and potassium } \\
\text { permanganate } \\
\text { KMnO4 }\end{array}$ & $\begin{array}{l}\text { Rectangular mat } \\
\text { (13 wt.\%) }\end{array}$ & & $\begin{array}{c}28 \\
\text { E: } 910\end{array}$ & $\begin{array}{c}54 \\
\text { Ef: } 3800\end{array}$ & & $7.3 \mathrm{KJ} / \mathrm{m}^{2}$ & & ILSS: $2 \mathrm{MPa}$ & {$[51]$} \\
\hline Epoxy/NaOH & $\begin{array}{c}\text { Chopped randomly (30\%, } \\
40 \% \text { and } 50 \% \mathrm{Vf})\end{array}$ & & 18 & 55 & 105 & $0.68 \mathrm{~J}$ & & & [63] \\
\hline
\end{tabular}


Table 5. Cont

\begin{tabular}{|c|c|c|c|c|c|c|c|c|c|}
\hline $\begin{array}{c}\text { Resin/Fiber } \\
\text { Treatment }\end{array}$ & $\begin{array}{l}\text { Fiber Size, Shape, and } \\
\text { Composition Vf/wt. } \%\end{array}$ & Hybrid/Filler & $\begin{array}{l}\text { Tensile } \\
\text { (MPa) }\end{array}$ & Flexural (MPa) & $\begin{array}{l}\text { Compression } \\
\text { (MPa) }\end{array}$ & Impact & Hardness & Other & Ref. \\
\hline Epoxy/NaOH & $\begin{array}{c}6 \mathrm{~cm} \\
(30 \% \mathrm{Vf})\end{array}$ & $\begin{array}{c}\text { Silica } \\
\text { nanoparticles }\end{array}$ & $\begin{array}{c}13 \\
\text { E: } 3284\end{array}$ & 28.9 & 81 & $0.9 \mathrm{~J}$ & & & {$[61]$} \\
\hline $\begin{array}{l}\text { Epoxy } / \mathrm{NaOH}, \\
\text { acetic acid }\end{array}$ & $\begin{array}{c}2 \mathrm{~mm} \\
(8,9,9.5 \text { and } 10 \mathrm{wt} . \%)\end{array}$ & $\begin{array}{l}\text { Lignite Fly Ash } \\
\text { filler }\end{array}$ & 17.28 & 46.87 & 48.13 & & $98 \mathrm{RHN}$ & & {$[54]$} \\
\hline Epoxy & $\begin{array}{c}\text { Rectangular mat }(8,13 \text {, and } \\
19 \text { wt. } \%)\end{array}$ & & 16.76 & 24.825 & & & & ILSS: $1.38 \mathrm{MPa}$ & {$[88]$} \\
\hline Epoxy/NaOH & $\begin{array}{c}2-5 \mathrm{~mm} \\
(3.2-9.6 \mathrm{wt} . \%)\end{array}$ & & E: 5560 & & & & & $\begin{array}{l}\text { Vibration: } \\
325.108 \mathrm{~Hz}\end{array}$ & {$[25]$} \\
\hline Epoxy & & Ceramic fibers & 140.68 & & $8.22 \mathrm{KN}$ & $2 \mathrm{~J}$ & $77.3 \mathrm{RHN}$ & & {$[84]$} \\
\hline Epoxy/NaOH & $2 \mathrm{~mm}$ & Carbon fibers & 60.48 & 98.71 & 78.46 & & $92 \mathrm{RHN}$ & & [133] \\
\hline Polyester & 30 wt. $\%$ & $\begin{array}{l}\text { Natural fillers } \\
\text { (ground nut } \\
\text { shell, rice husk, } \\
\text { and wood } \\
\text { powder) (3, } 7 \\
\text { and11 WT.\%) }\end{array}$ & 31.5 & & & $9 \mathrm{~J}$ & $13.3 \mathrm{Hv}$ & $\begin{array}{c}\text { Wear: } \\
0.0284150 \\
\mathrm{~mm}^{3} / \mathrm{Nm}\end{array}$ & {$[24]$} \\
\hline $\begin{array}{l}\text { Polyester } / \mathrm{NaOH}, \\
\text { hydrogen peroxide, } \\
\text { acetic anhydride, } \\
\text { and acetone }\end{array}$ & & & & $\begin{array}{c}52.3 \\
\text { Ef: } 3290\end{array}$ & & & & & {$[65]$} \\
\hline $\begin{array}{l}\text { Polyester/ } \mathrm{NaOH}, \\
\text { meth-acrylamide }\end{array}$ & $\begin{array}{l}\text { Short fibers and mat } \\
\quad(24.5-42.6 \% \mathrm{Vf})\end{array}$ & & $\begin{array}{c}22 \\
\text { E: } 5200\end{array}$ & & & $3.71 \mathrm{KJ} / \mathrm{m}^{2}$ & & & {$[60]$} \\
\hline Polyester & $20 \mathrm{~mm}(15-30 \% \mathrm{Vf})$ & E-glass & & $\begin{array}{c}30.1 \\
\text { Ef: } 1710\end{array}$ & & & & & {$[94]$} \\
\hline Polyester & $\begin{array}{c}\text { Mat } \\
(10,20,30 \text { and } 40 \mathrm{wt} . \%)\end{array}$ & & & & & $1.12 \mathrm{~J}$ & & & {$[96]$} \\
\hline Polyester $/ \mathrm{NaOH}$ & Strips $120 \times 25 \mathrm{~mm}(30 \% \mathrm{Vf})$ & & & $\begin{array}{c}46.4 \\
\text { Ef: } 3220\end{array}$ & & & & & {$[70]$} \\
\hline
\end{tabular}


Table 5. Cont

\begin{tabular}{|c|c|c|c|c|c|c|c|c|c|}
\hline $\begin{array}{c}\text { Resin/Fiber } \\
\text { Treatment }\end{array}$ & $\begin{array}{l}\text { Fiber Size, Shape, and } \\
\text { Composition Vf/wt.\% }\end{array}$ & Hybrid/Filler & $\begin{array}{l}\text { Tensile } \\
\text { (MPa) }\end{array}$ & Flexural (MPa) & $\begin{array}{l}\text { Compression } \\
\text { (MPa) }\end{array}$ & Impact & Hardness & Other & Ref. \\
\hline $\begin{array}{l}\text { Polyester/methyl } \\
\text { ethyl ketone } \\
\text { peroxide }\end{array}$ & Mat $250 \times 100 \mathrm{~mm}$ & & 23.893 & & & & & & [56] \\
\hline $\begin{array}{l}\text { Polyester } / \mathrm{NaOH}, \\
\text { hydrogen peroxide } \\
\text { acetic anhydride, } \\
\text { and acetone }\end{array}$ & $\begin{array}{c}\text { Mat } \\
(5-15 \text { wt.\%) }\end{array}$ & & & $\begin{array}{c}41.96 \\
\text { Ef: } 2690\end{array}$ & & & & & [66] \\
\hline $\begin{array}{c}\text { RF/Calcium } \\
\text { phosphate and } \\
\text { calcium carbonate }\end{array}$ & 50 wt. $\%$ & & $\begin{array}{l}14.88 \\
\text { E: } 680\end{array}$ & $\begin{array}{c}80.67 \\
\text { Ef: } 3338\end{array}$ & 70.28 & & & & [78] \\
\hline $\begin{array}{c}\mathrm{RF} / \mathrm{NaOH}, \mathrm{CaCl} 2, \\
\mathrm{H} 2 \mathrm{SO} 4, \text { and } \\
\mathrm{Na} 2 \mathrm{HPO} 4\end{array}$ & $\begin{array}{c}2 \mathrm{~cm} \\
(10-50 \mathrm{wt} . \%)\end{array}$ & & $\begin{array}{l}29.438 \\
\text { E: } 1662\end{array}$ & & 81.00 & & & & {$[57]$} \\
\hline Formaldehyde & $\begin{array}{l}\text { Mat in medium density } \\
\text { fireboard }\end{array}$ & $\begin{array}{c}\text { Pine, beech and } \\
\text { oak }\end{array}$ & & 50.91 & & & & & [97] \\
\hline Polyurethane & Mat & Glass fiber & 12.7 & & & & & & [99] \\
\hline $\begin{array}{l}\mathrm{PP} / \mathrm{NaOH} \text { and } \\
\text { silane coupling } \\
\text { agent }\end{array}$ & $2-15$ wt. $\%$ & & 35 & & & & & & [68] \\
\hline $\begin{array}{l}\text { Bio-based } \\
\text { polyethylene } \\
\text { (HDPE) }\end{array}$ & $(10,20,30$ and 40 wt.\%) & & $\begin{array}{c}21.2 \\
\text { E: } 2082\end{array}$ & 37.7 & & $33.3 \mathrm{~J} / \mathrm{m}$ & & & [98] \\
\hline $\begin{array}{l}\text { Vinyl ester/ethanol, } \\
\text { NaOH, BTDA } \\
\text { dianhydrides }\end{array}$ & $\begin{array}{c}\text { Mat } \\
(15 \text { wt. } \%)\end{array}$ & & 21.2 & & & & & DMA: & [64] \\
\hline $\begin{array}{c}\text { Polylactic } \\
\text { acid/NaClO }\end{array}$ & $\begin{array}{c}2 \mathrm{~cm} \\
(2,5 \text { and } 10 \mathrm{wt} . \%)\end{array}$ & & $\begin{array}{c}36.44 \\
\text { E: } 2997.45\end{array}$ & $\begin{array}{c}48.64 \\
\text { Ef: } 3939\end{array}$ & & $28.19 \mathrm{~J} / \mathrm{m}$ & & & {$[58]$} \\
\hline Geopolymer & $\begin{array}{c}\text { Fiber's D: } 200 \mu \mathrm{m} \text {. L: } 160 \\
\mathrm{~mm} . \\
(10 \text { vol. } \%)\end{array}$ & & & 14.2 & 31 & & & & {$[100]$} \\
\hline
\end{tabular}


Table 5. Cont

\begin{tabular}{|c|c|c|c|c|c|c|c|c|c|}
\hline $\begin{array}{c}\text { Resin/Fiber } \\
\text { Treatment }\end{array}$ & $\begin{array}{l}\text { Fiber Size, Shape, and } \\
\text { Composition Vf/wt.\% }\end{array}$ & Hybrid/Filler & $\begin{array}{l}\text { Tensile } \\
\text { (MPa) }\end{array}$ & Flexural (MPa) & $\begin{array}{l}\text { Compression } \\
\text { (MPa) }\end{array}$ & Impact & Hardness & Other & Ref. \\
\hline Concrete & Mat & & & 10.2 & 25.8 & & & & {$[103]$} \\
\hline $\begin{array}{c}\text { Pre-gelatinized } \\
\text { cassava starch }\end{array}$ & $\begin{array}{c}3-5 \mathrm{~mm} \\
(5,10,15, \text { and } 20 \mathrm{wt} . \%)\end{array}$ & & 1.24 & & & & & & {$[101]$} \\
\hline $\begin{array}{c}\text { Pure luffa/ } \mathrm{NaOH}, \\
\mathrm{H} 2 \mathrm{O} 2 \\
\mathrm{CH} 3 \mathrm{COOH}\end{array}$ & 30-40 mm/Bundle & & $\begin{array}{l}74.23 \\
\text { E: } 820\end{array}$ & & & & & & [55] \\
\hline $\begin{array}{l}\text { Pure luffa/glacial } \\
\text { acetic acid and } \\
\text { hydrogen peroxide }\end{array}$ & 220 and $30 \mathrm{~mm}$ & & $\begin{array}{l}91.63 \\
\text { E: } 1897\end{array}$ & & & & & & {$[27]$} \\
\hline $\begin{array}{l}\text { Pure luffa/thermo- } \\
\text { hydromechanical } \\
\text { treatment }\end{array}$ & & & 177.93 & & & & & & \\
\hline Pure Luffa & & & & & 0.74 & & & & [77] \\
\hline Pure luffa & & & $\begin{array}{c}120 \\
\text { E: } 2300\end{array}$ & & 0.37 & & & & [47] \\
\hline Pure luffa & Specimen's D: $42-81 \mathrm{~mm}$ & & & & 0.40 & & & & {$[46]$} \\
\hline
\end{tabular}




\subsubsection{Tensile Properties}

Luffa natural fiber composite studies have mostly considered the tensile behavior compared to other mechanical properties, aiming to define the elastic behavior of this NFC, i.e., ultimate tensile strength as well as Young's modulus. Tensile strength (TS) of LNFCs increased by increasing fiber content up to $40 \mathrm{wt} . \%$, but it started to decrease at $50 \mathrm{wt} . \%$ [59,62]. Thus, Mani et al. [134] reported an increment in the tensile strength of luffa mat/epoxy NFC followed by a decrement when adding fibers beyond $40 \mathrm{wt} . \%$. However, by considering chopped luffa fibers, $50 \mathrm{wt} . \%$ revealed the highest strength. In a sandwich structure, the tensile strength of LNFC increased by increasing fiber content up to two luffa layers then decreased by adding a third layer [90]. Generally, LNFC made with NaOH-treated fibers exhibited higher tensile strength compared to that of untreated fibers [49,51,60]. Moreover, benzoyl treatment showed better property improvement than alkali and $\mathrm{KMnO}_{4}$ treatments [51]; in addition, BTDA dianhydrides (tetracarboxylic benzophenone dianhydrides) revealed the best TS increment compared to ethanol and $\mathrm{NaOH}$ treatments [64]. However, Furfuryl Alcohol-grafted LNFC revealed a notable improvement in tensile strength (100\%) and tensile modulus (123\%), which were higher than the ones obtained by NaOH-treated LNFC [50]. Superior TS can be obtained by hybridizing LNFC with natural or synthetic fibers such as ceramic B4C, which improved TS around $8.6 \%$ [44], glass fiber (up to 100.4\%) [88,91], and ground nut shell. In contrast, hybridization of LNFC with wood powder or rice husk reduced its tensile strength [24]. Adding silane coupling agent into luffa/polypropylene NFC can deteriorate its TS, whereas increasing the luffa fiber volume fraction reduced the tensile strength [68]. In single luffa fiber testing, $10 \% \mathrm{NaOH}$ treatment for $30 \mathrm{~min}$ at $40{ }^{\circ} \mathrm{C}$ worked best in improving the fiber's tensile strength [55].

As clearly shown in Table 5 and Figure 6, peak tensile strength of LNFC was observed in an epoxy matrix, followed by polylactic acid and polypropylene. However, the highest LNFC tensile strength reported was $226 \mathrm{MPa}$ in an epoxy matrix, followed by $140 \mathrm{MPa}$ in a ceramic/luffa/epoxy hybrid NFC. Hence, LNFC with polylactic acid matrix reached a tensile strength of $36.44 \mathrm{MPa}$ and a tensile modulus of around $3 \mathrm{GPa}$; thus, luffa in a polypropylene matrix exhibited $35 \mathrm{MPa}$ TS. Luffa NFC revealed a tensile strength of $31.5 \mathrm{MPa}$ with a polyester matrix, $29 \mathrm{MPa}$ in resorcinol-formaldehyde, $21 \mathrm{MPa}$ in bio-based high-density polyethylene as well as in vinyl ester, and lower tensile strength was observed in a polyurethane matrix (12.7 MPa). In terms of pure luffa, the peak tensile strength observed was 177.93 MPa after treating fibers with a thermo-hydro-mechanical technique. Paglicawan et al. [135] mentioned that the stress and strain curve of luffa/polyester NFC was similar to the curve of brittle materials, hence it behaves elastically as stress and stress increases in linear trend.

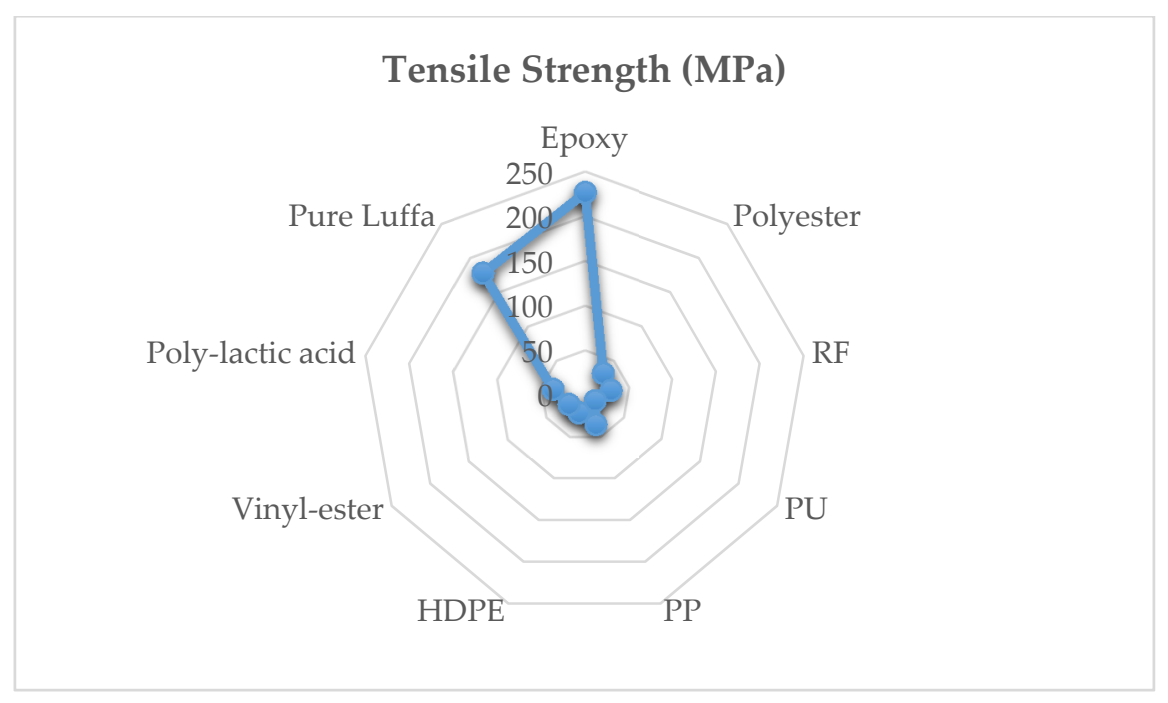

Figure 6. Tensile strength of luffa natural fiber composites. 


\subsubsection{Flexural Properties}

Increasing fiber volume fraction enhanced the flexural strength of LNFC, as these fibers helped enduring bending loads throughout the brittle resin [59], yet adding fibers beyond $50 \mathrm{wt} . \%$ decreased the flexural strength of the end LNFC [62]. Chemically treating luffa fibers with $\mathrm{NaOH}$, acetic anhydride, or acetone can result in higher flexural strength than those of untreated fibers $[65,66]$. Benzoyl treatment exhibited better bending properties enhancement, compared to $\mathrm{KMnO} 4$ and alkali treatments [51]. Hybridizing LNFC with flax fibers [49] or glass fibers [91] can reveal greater flexural strengths, especially when luffa is considered as a core layer in laminate structure [88]. However, the flexural strength of LNFCs increased by increasing fiber content up to two luffa layers, then showed a decrease by adding a third layer [90]. As we can see in Table 5, maximum flexural strength observed was 115 MPa with $\mathrm{NaOH}$-treated luffa fibers and epoxy, followed by $108 \mathrm{MPa}$ in glass/luffa/epoxy hybrid natural fiber composite. Moreover, selecting Resorcinol-Formaldehyde as a matrix produced a flexural strength of around $80 \mathrm{MPa}$, while luffa/polyester NFC reached 52.3 MPa flexural strength. Lower values were observed in LNFC with a geopolymer matrix (14.2 MPa) and concrete (10.2 MPa).

\subsubsection{Compression Properties}

In contrast with the aforementioned mechanical properties, compressive strength of luffa natural fiber composites decreased by increasing fiber composition (wt.\%) [59,78]. Optimum compressive strength can be obtained in an NFC with a fiber volume fraction around 30\% [62]. Chemically treated luffa fibers contributed to around 6\% higher compressive strength [57], and adding nanofillers like ceramic $\mathrm{B} 4 \mathrm{C}$ [44] or $\mathrm{SiO}_{2}$ [61] can reveal superior compression strengths. Table 5 shows that the highest compressive strength reported was $107 \mathrm{MPa}$ and $105 \mathrm{MPa}$ in $\mathrm{NaOH}$-treated luffa fibers and epoxy matrix, respectively. Furthermore, reinforcing resorcinol-formaldehyde with luffa chopped fibers reached a compressive strength of $81 \mathrm{MPa}$, while lower compressive characteristics were exhibited in an LNFC with a geopolymer matrix (31 MPa) and concrete matrix (around $29 \mathrm{MPa}$ ). Hence, highest compressive strength reported for pure luffa was $0.74 \mathrm{MPa}$.

\subsubsection{Impact Properties}

The toughness of LNFCs can be raised through increasing fiber volume fraction [24,50]. However, NagarajaGanesh et al. [96] indicated that $30 \mathrm{wt} . \%$ revealed the highest impact strength in luffa/polyester NFC, whereas Anbukarasi et al. [59] observed maximum toughness in samples with $40 \mathrm{wt} . \%$ treated mat/epoxy, as it showed $163.6 \%$ impact strength improvement. Moreover, chemical treatments enhanced the impact strength of luffa fibers $[49,60]$. Sodium hydroxide treatment had higher fiber toughness improvement compared with sodium chlorite and acetic acid [50]. Furthermore, fibers treated with $\mathrm{KMnO}_{4}$, benzoyl chloride, and $\mathrm{NaOH}$ exhibited $36 \%, 49 \%$, and $32 \%$ higher toughness, respectively, than untreated luffa fibers [51]. Some natural fibers and nanofillers showed their compatibility with LNFC, such as ground nut shells [62,96], and $\mathrm{B}_{4} \mathrm{C}$ that improved the toughness by $\sim 54 \%$ [44]. It is worthy to mention that the impact strength can be highly affected by the fiber's shape and volume [90]. As Table 5 shows, the most significant impact strengths were observed in LNFC with an epoxy matrix.

\subsubsection{Hardness}

Few studies have investigated the hardness of LNFCs, aiming to determine the effect of layer number in a sandwich structure, or the difference after adding nanofillers or other natural fibers. Reinforcing epoxy matrix with two layers of luffa mat exhibited peak hardness, while adding a third layer led to hardness deterioration [90]. Addition of ceramic $\mathrm{B}_{4} \mathrm{C}$ nanoparticles contributed to increasing the hardness of LNFC around 8 HRC [44]. Similarly, hybridizing LNFC with ground nut shell improved its hardness in contrast with wood flour and rice husk, which reduced this property [24]. As illustrated in Table 5, peak hardness value reported was 98 RHN in treated luffa/epoxy NFC, 
followed by $92 \mathrm{RHN}$ in hybrid NaOH-treated luffa/carbon/epoxy hybrid NFC. Moreover, LNFC with a polyester matrix revealed a hardness of $13.3 \mathrm{Hv}$.

\subsubsection{Wear, Shear, Vibration, and Dynamic Mechanical Analysis}

A material is brittle or ductile due to its erosion rate versus angle of impingement. A material is classified brittle if the highest erosion happens at a $90^{\circ}$ impact angle, while a material is considered ductile if the peak erosion rate occurs on a low angle of impingement (below 30 ${ }^{\circ}$ [90]. In LNFCs, a ductile to brittle transition was observed by increasing the fiber content (from two layers to three layers); however, the impingement angle switched from $45^{\circ}$ to $60^{\circ}$ [90]. Regarding the abrasive wear of LNFC, increasing the fiber volume fraction increased the wear rate because of the degraded matrix/fiber adhesion [24]. Interlaminar shear stress (ILSS) describes the stresses affecting the interface of two plies of a composite material in a sandwich structure. Moreover, these stresses can deform the connection between these two plies and lead the composite to split if the stresses are adequate [91]. ILSS of NFCs exhibited a continuous increase simultaneous to fiber weight increment $[88,90]$. ILSS was enhanced around $95 \%$ by chemically treating luffa fibers with sodium hydroxide [51]. Regarding the vibration behavior of LNFCs, increasing the thickness ratio as well as the aspect ratio reduced the frequency response [25]. In terms of the dynamic mechanical behavior of LNFCs, exposing this composite material to a second heating cycle showed an increase in the storage modulus as well as the loss modulus. However, the improved surface of the chemically treated fibers contributed to enhancing the matrix/fiber bonding and thereby increased the loss and storage modulus [64]. However, Kalusuraman et al. [71] reported highest damping peak in samples with $50 \mathrm{wt} . \%$ luffa fibers treated with $\mathrm{CaOH}_{2}$, and highest loss modulus in specimens with $50 \mathrm{wt} . \%$ silane-treated luffa fibers.

\subsection{Chemical, Thermal, and Electrical Properties}

Thermal properties of LNFC specify its behavior when exposed to high temperatures, which involves several core aspects like melting point, thermal degradation, and crystallinity degree. Thus, additional properties such as electrical and chemical are imperative in proving the reliability of LNFC. Lately, different tests have been conducted in the area of LNFCs, e.g., Fourier-transform infrared spectroscopy (FTIR), thermogravimetric analysis (TGA), chemical, differential scanning calorimetry, etc.

\subsubsection{Fourier-Transform Infrared Spectroscopy}

The general infrared spectrum properties of luffa fibers are primarily due to lignin, hemicelluloses, and $\alpha$-cellulose [136]. FTIR was carried out for LNFCs with an epoxy matrix [50,51,61], polyester [65,96], vinyl ester [64], resorcinol-formaldehyde [78], pre-gelatinized cassava starch [101], as well as pure luffa fiber $[55,69]$. FTIR results of the aforementioned LNFCs showed dissimilar spectra trends, as well as different peak numbers and positions, which was due to the distinct fiber treatment types, percentage, and methods

Fourier-transform infrared spectra researches confirmed the hydrophilic nature of luffa fibers [96]. Luffa fibers treated with $\mathrm{NaOH}, \mathrm{KMnO}_{4}$, and benzoyl chloride showed lower absorption spectra than untreated luffa fibers, due to the elimination of non-polar covalent components such as fat, wax, and so on. Moreover, benzoyl chloride chemical treatment exhibited the greatest spectra reduction compared to other chemical treatments, although after chemical modifications the main functional components of luffa fibers remained the same [51]. After treatment with sodium hydroxide, the band of pure luffa fibers at $1245 \mathrm{~cm}^{-1}$ completely disappeared, and the band at $1375 \mathrm{~cm}^{-1}$ significantly decreased, which showed that the partial acetyl elements in the hemicellulose and lignin dissolved in the alkaline [55]. However, addition of luffa fibers into a carbohydrate matrix like pre-gelatinized cassava starch (TPS) displayed negligible changes on the FTIR spectra due to the identical chemical structure of the matrix and the fibers. Hence, addition of luffa fibers slightly reduced the $\mathrm{OH}$ stretching peak of gelatinized cassava starch (from $3404 \mathrm{~cm}^{-1}$ to $3395 \mathrm{~cm}^{-1}$ ), which indicated the creation of hydrogen bonds between the gelatinized cassava starch and luffa fibers [101]. 


\subsubsection{Chemical}

Akgül et al. [97] tested the chemical behavior of luffa fibers, and the results showed that its chemical components consisted of $0.37 \%$ ash, $14.04 \%$ lignin, $62.34 \% \alpha$-cellulose, and $84.84 \%$ holocellulose. Moreover, luffa had the following solubility: $16.38 \%$ in $1 \% \mathrm{NaOH}, 4.5 \%$ in cold water, $3.30 \%$ in hot water, and $0.25 \%$ in alcohol-benzene. However, luffa exhibited a solubility comparable to hardwood solubility when compared with other annual plants like hazelnut husk, cotton stalks, corn stalks, cotton carpel, cereal straw, softwood, and hardwood. Luffa revealed higher content of $\alpha$-cellulose and holocellulose, whereas ash and lignin contents were lower than almost all compared plants [97].

\subsubsection{Thermogravimetric}

Thermogravimetric analysis (TGA) is a testing technique that indicates the mass loss of a material upon temperature exposure for a time period [137]. TGA was conducted for LNFCs with the following matrices: epoxy [50,51,59], polyester [94,96], TPS [101], vinyl ester [64], resorcinol-formaldehyde resin [78], and pure luffa [27,69]. Figure 7 shows a TGA of treated and untreated luffa fibers.

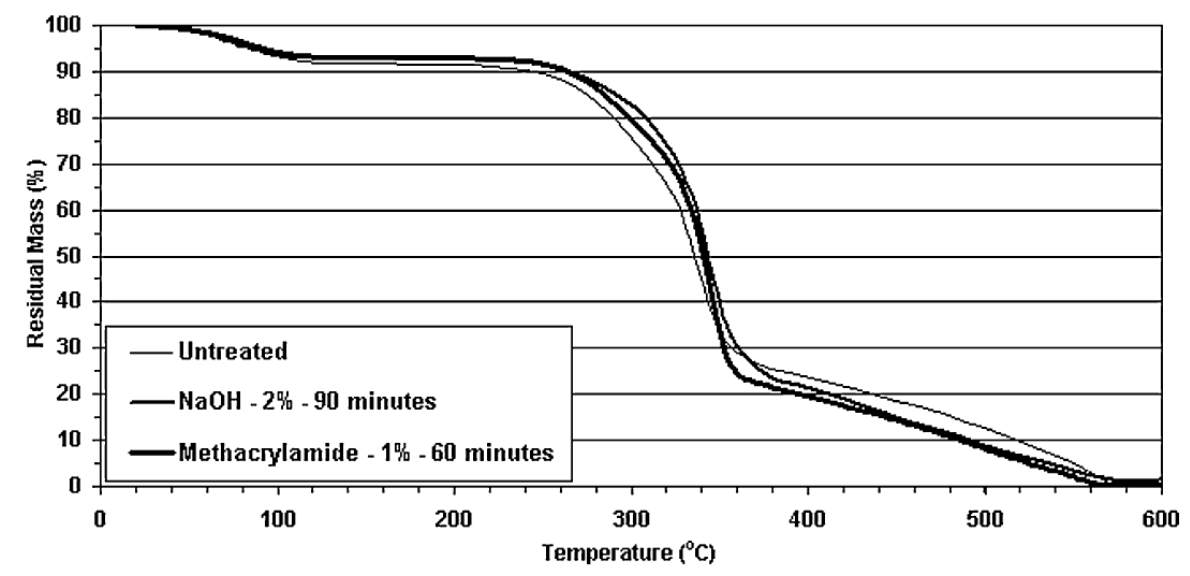

Figure 7. Thermogravimetric analyses of treated as well as untreated luffa fibers. Adapted with permission from ref. [69]. Copyright 2020, Elsevier.

Luffa fibers lost $7.25 \%$ of their weight in the temperature range between $49^{\circ} \mathrm{C}$ and $118^{\circ} \mathrm{C}$ due to the evaporation of water, then lost $46.5 \%$ between $118{ }^{\circ} \mathrm{C}$ and $322^{\circ} \mathrm{C}$ due to the thermal oxidative degradation of lignin, cellulose, and hemicelluloses; hence, they lost $35.69 \%$ between $322{ }^{\circ} \mathrm{C}$ and $455{ }^{\circ} \mathrm{C}$ due to char creation. It is worth mentioning that hemicellulose decomposition occurred at a temperature ranging from $160^{\circ} \mathrm{C}$ to $250{ }^{\circ} \mathrm{C}$ [96].

Thermal resistance of luffa fibers slightly increased when the fibers were treated. Temperatures beyond $250{ }^{\circ} \mathrm{C}$ caused the highest mass changes as these fibers reached a drastic level of thermal degradation [69]. However, the thermal stability of untreated luffa fibers was lower than that of chemically treated luffa fiber. Compared with benzoyl chloride and $\mathrm{NaOH}, \mathrm{KMnO}_{4}$ chemical treatment showed the best improvement in the thermal stability of luffa fibers [51]. Furthermore, adding luffa fibers to a matrix like TPS can enhance its thermal stability [101]. Thus, LNFC can endure temperatures up to $800^{\circ} \mathrm{C}$ before its decomposition [78].

\subsubsection{Differential Scanning Calorimetric}

Differential scanning calorimetric (DSC) analysis was carried out by Tanobe et al. [60] on the polyester matrix to specify its curing temperature and curing time at a heating rate of $10^{\circ} \mathrm{C} / \mathrm{min}$ from $20^{\circ} \mathrm{C}$ to $180{ }^{\circ} \mathrm{C}$ for each specimen. DSC results of pure polyester exposed to $70{ }^{\circ} \mathrm{C}$ showed that the curing began straight after combining the resin with hardener, and took around $10 \mathrm{~min}$ to complete 
at $120^{\circ} \mathrm{C}$, whereas DSC results of untreated LNFC indicated that the resin was partially cured at $80^{\circ} \mathrm{C}[60]$.

All luffa/epoxy NFCs revealed two transition peaks, an exothermic peak above $200{ }^{\circ} \mathrm{C}$, and endothermic peak at $\sim 100{ }^{\circ} \mathrm{C}$. The endothermic peak of untreated LNFCs was observed at $\sim 100{ }^{\circ} \mathrm{C}$, caused by moisture vaporization from the fibers. However, in treated LNFCs, the aforementioned peak was observed at higher temperatures (FA-grafted NFC at $110^{\circ} \mathrm{C}$ and $\mathrm{NaOH}$-treated NFC at $106^{\circ} \mathrm{C}$ ). Furthermore, the curing reaction enthalpy ( $\Delta$ Hcure) of neat epoxy was slightly lower than that of LNFCs [50].

\subsubsection{Dielectric}

The dielectric behavior of LNFC revealed greater constants upon increasing the fiber volume fraction; for instance, the addition of heat-treated luffa fibers into a Polylactic acid matrix exhibited higher dielectric constants compared to pure PLA at all applied frequencies, yet increasing the frequency decreased the dielectric constants [80]. The interfacial polarization produced between the dipoles of the matrix and fibers was the main reason for the notable dielectric constant revealed in LNFC [138]. However, the hybrid luffa/coir NFC exhibited a dielectric constant similar to that of composite materials made with synthetic fibers [74].

\section{Hybrid}

The characteristics of hybrid LNFC depend on the failure strain of each fiber type considered, fiber orientation, fiber volume fraction, fiber length, fiber/matrix adhesion, fiber layup [139]. The highest properties can be reached once the strains of both hybridized fibers are notably compatible, property results [140]. Table 6 lists the major selected fibers utilized for hybridization of LNFC.

Table 6. Hybrid LNFCs.

\begin{tabular}{ccc}
\hline Resin/Coupling Agent/Hardener & Hybrid/Filler & Reference \\
\hline Epoxy & Ground nut $(1: 1)$ & {$[62]$} \\
Epoxy & Flax & {$[49]$} \\
Epoxy & Jute & {$[93]$} \\
Epoxy & Ceramic $\mathrm{B}_{4} \mathrm{C}(10 \mathrm{wt} . \%)$ & {$[44]$} \\
Epoxy & Glass fiber & {$[91]$} \\
Epoxy & Glass fiber & {$[141]$} \\
Epoxy & Carbon fiber & {$[133]$} \\
Epoxy & Silica nanoparticles & {$[61]$} \\
Epoxy & Lignite fly ash filler & {$[54]$} \\
Epoxy & Lead oxide nanofiller & {$[73]$} \\
Epoxy & Coir & {$[74]$} \\
Polyester & Natural fillers (ground nut shell, rice husk, & {$[24]$} \\
Polyester & and wood powder) $(3,7$, and 11 wt.\%) & {$[94]$} \\
Polyester & E-glass & {$[142]$} \\
PU foams & TiO ${ }_{2}$, Al $\mathrm{O}_{3}$, and CaCO & {$[45]$} \\
PU & Tea leaf (main in the study) & {$[99]$} \\
formaldehyde & Glass fiber & {$[97]$} \\
Poly (Butylene & Pine, beech, and oak & {$[143]$} \\
\hline Succinate-Co-Lactate)/starch blends & Kenaf & \\
\hline
\end{tabular}

As shown in Table 6, mostly hybrid LNFCs were considered in an epoxy matrix, yet luffa/epoxy NFCs were hybridized with several natural fibers like ground nut, flax, jute, fly ash, coir, etc., and with different synthetic fibers, viz., glass and carbon fibers. Hence, other LNFCs with a polyester matrix were hybridized with wood powder, rice husk, ground nut shell, E-glass, and so on. Generally, hybridizing LNFC with other fibers reveals greater mechanical characteristics [49]. The addition of luffa and tea leaf fibers to polyurethane foam exhibited significant acoustic properties [45]. In terms 
of the luffa/glass hybrid NFC, optimal flexural and tensile strengths were obtained by considering two glass fiber plies as outer layers and two luffa plies as a core [91]. Adding B4C into the luffa/epoxy NFC enhanced its tensile properties by $8.55 \%$ and compressive properties by $67 \%$, yet reached a hardness of $91 \mathrm{HRC}$ [44]. $\mathrm{SiO}_{2}$ nanoparticles contributed to increasing the mechanical properties around 2\% [61]. Similarly, fly ash filler was able to enhance the tensile strength of LNFC by improving the matrix-to-fiber adhesion [54]. However, in the luffa/polyester NFC, adding wood powder, rice husk, and ground nut shell improved the physical and mechanical properties [24].

\section{Conclusions}

The aim of this review paper is to compile, categorize, and compare the research in the area of LNFCs, taking into consideration their physical, morphological, mechanical, thermal, electrical, and acoustic properties, shedding light on the matrix types, fiber sizes, fiber volume fractions, and fiber treatments. Diverse chemical treatments were utilized to modify the characteristics of luffa fibers, e.g., sodium hydroxide, hydrogen peroxide, acetic acid, benzoyl chloride, acetone, $\mathrm{HCl}$, etc. In addition, thermo-mechanical, thermo-hydro-thermal, and heat treatments were implemented. Luffa fibers were considered as a reinforcement for various types of matrixes, such as epoxy, polyester, formaldehyde, polylactic acid, high-density polyethylene, vinyl ester, polyurethane, and so on. Scanning electron microscopy showed that luffa has a flake-like, fatty, and waxy structure. Moreover, increasing the fiber-loading in LNFC reduced its crystallinity and increased the crystallite size. Regardless of the chosen matrix, LNFC densities ranged between 0.717 and $1.38 \mathrm{~g} / \mathrm{cm}^{3}$. However, addition of luffa fibers into polymeric matrices was able to increase the overall water absorption. LNFCs exhibited significant sound absorption coefficients throughout all fiber volume fractions. In terms of the mechanical behavior of LNFCs, the highest mechanical properties were observed through selecting epoxy resin as a matrix, for example, the highest tensile strength of $226 \mathrm{MPa}$, flexural strength of $115 \mathrm{MPa}$, compressive strength of $107 \mathrm{MPa}$, and hardness of $98 \mathrm{RHN}$. Furthermore, chemically treating these fibers showed a notable effect on the mechanical characteristics of the end LNFC. Hence, the chemical composition of luffa fibers exhibited higher holocellulose and $\alpha$-cellulose content, compared to other natural fibers, yet it had lower ash and lignin contents. Some hybrid LNFCs had dielectric constants similar to those of syntactic composite materials. Different natural and synthetic fibers were utilized to hybridize LNFC, such as flax, jute, coir, tea leaf, ground nut, glass, carbon, etc., which commonly contributed to exhibiting greater properties compared to pure LNFCs. Several researches proposed the involvement of LNFC in building, printed circuit boards (PCBs), and further applications. Acoustic, thermal, and chemical properties as well as the dimensional stability of LNFC still need more research. In addition, the utilization of LNFC in household goods, sports, automotive, aerospace, and other industrial areas needs further investigation. Furthermore, not many researchers have utilized design of experiments (DOE) to conduct experimentation. However, DOE is a useful scientific method that helps plan and organize experiments in order to reach valid conclusions through analyzing the obtained results. In other words, it reduces the time and resources to make experiments, eliminates redundant observations, and provides points that can be used to create a meta-model by involving a smart exploration of the design space. Moreover, machine learning techniques like Artificial Neural Networks (ANNs) are widespread approximators that are usually involved in regression tasks and classification; thus, these techniques are highly capable of approximating the properties of LNFC.

Future research in the LNFC area needs to focus on the consideration of polymeric recycled matrices, the modeling and simulation of LNFCs, the analytical analysis of LNFC, such as using Halpin-Tsai or Cox models to predict the tensile strength, Hirsch's model for Young's modulus, Hashin's approach for fatigue criteria, the Johnson-Champoux-Allard technique to analyze the sound absorption, and Fourier's heat conduction equation to predict the thermal characteristics, in addition to the implementation of optimization algorithms in order to get optimal parameters, and the design of experiment approaches for the variation analysis. 
Author Contributions: All authors have read and agreed to the published version of the manuscript. M.A. (Mohamad Alhijazi) was responsible for Data curation, Resources, Visualization. B.S. was responsible for Investigation. Q.Z. was responsible for Supervision, Methodology. B.S., Q.Z., M.A. (Mohammed Asmael), M.A. (Mohamad Alhijazi), A.E. and Z.Q. were responsible for Writing-original draft and Writing-review \& editing. B.S. and Q.Z. were responsible for Project administration. All authors have read and agreed to the published version of the manuscript.

Funding: This research received no external funding.

Conflicts of Interest: The authors declare no conflict of interest.

\section{References}

1. Yusuf, S.; Islam, N.; Ali, H.; Akram, W.; Siddique, A. Impact Strength of Natural Fiber Reinforced Composites: Taguchi Method. Adv. Mater. Sci. 2020, 20, 54-70. [CrossRef]

2. Yuan, Y.; Zhao, K.; Zhao, Y.; Sahmani, S.; Safaei, B. Couple stress-based nonlinear buckling analysis of hydrostatic pressurized functionally graded composite conical microshells. Mech. Mater. 2020, 148, 103507. [CrossRef]

3. Yuan, Y.; Zhao, K.; Han, Y.; Sahmani, S.; Safaei, B. Nonlinear oscillations of composite conical microshells with in-plane heterogeneity based upon a couple stress-based shell model. Thin-Walled Struct. 2020, 154, 106857. [CrossRef]

4. Mitra, B. Environment friendly composite materials: Biocomposites and green composites. Def. Sci. J. 2014, 64, 244. [CrossRef]

5. Safaei, B. The effect of embedding a porous core on the free vibration behavior of laminated composite plates. Steel Compos. Struct. 2020, 35, 659-670.

6. Rajkumar, D.R.; Santhy, K.; Padmanaban, K.P. Influence of Mechanical Properties on Modal Analysis of Natural Fiber Reinforced Laminated Composite Trapezoidal Plates. J. Nat. Fibers. 2020, 1-17. [CrossRef]

7. Navaneethakrishnan, G.; Karthikeyan, T.; Saravanan, S.; Selvam, V.; Parkunam, N.; Sathishkumar, G.; Jayakrishnan, S. Structural analysis of natural fiber reinforced polymer matrix composite. Mater. Today 2020, 21, 7-9. [CrossRef]

8. Javanbakht, Z.; Hall, W.; Virk, A.S.; Summerscales, J.; Öchsner, A. Finite element analysis of natural fiber composites using a self-updating model. J. Compos. Mater. 2020, 54, 3275-3286. [CrossRef]

9. Fan, F.; Lei, B.; Sahmani, S.; Safaei, B. On the surface elastic-based shear buckling characteristics of functionally graded composite skew nanoplates. Thin-Walled Struct. 2020, 154, 106841. [CrossRef]

10. Huzaifah, M.; Sapuan, S.; Leman, Z.; Ishak, M.; Maleque, M. A review of sugar palm (Arenga pinnata): Application, fibre characterisation and composites. Multidiscip. Model. Mater. Struct. 2017, 13, 678-698. [CrossRef]

11. Behdinan, K.; Moradi-Dastjerdi, R.; Safaei, B.; Qin, Z.; Chu, F.; Hui, D. Graphene and CNT impact on heat transfer response of nanocomposite cylinders. Nanotechnol. Rev. 2020, 9, 41-52. [CrossRef]

12. Mazzanti, V.; Pariante, R.; Bonanno, A.; Ruiz de Ballesteros, O.; Mollica, F.; Filippone, G. Reinforcing mechanisms of natural fibers in green composites: Role of fibers morphology in a PLA/hemp model system. Compos. Sci. Technol. 2019, 180, 51-59. [CrossRef]

13. Sanjay, M.R.; Madhu, P.; Jawaid, M.; Senthamaraikannan, P.; Senthil, S.; Pradeep, S. Characterization and properties of natural fiber polymer composites: A comprehensive review. J. Clean. Prod. 2018, 172, 566-581. [CrossRef]

14. Davoodi, M.; Sapuan, S.; Ahmad, D.; Aidy, A.; Khalina, A.; Jonoobi, M. Effect of polybutylene terephthalate (PBT) on impact property improvement of hybrid kenaf/glass epoxy composite. Mater. Lett. 2012, 67, 5-7. [CrossRef]

15. Alhijazi, M.; Zeeshan, Q.; Safaei, B.; Asmael, M.; Qin, Z. Recent Developments in Palm Fibers Composites: A Review. J. Polym. Environ. 2020. [CrossRef]

16. Ishak, M.; Leman, Z.; Sapuan, S.; Rahman, M.; Anwar, U. Chemical composition and FT-IR spectra of sugar palm (Arenga pinnata) fibers obtained from different heights. J. Nat. Fibers. 2013, 10, 83-97. [CrossRef]

17. Moghaddam, M.K.; Mortazavi, S.M. Physical and chemical properties of natural fibers extracted from typha australis leaves. J. Nat. Fibers. 2016, 13, 353-361. [CrossRef]

18. Saravanakumar, S.; Kumaravel, A.; Nagarajan, T.; Moorthy, I.G. Investigation of physico-chemical properties of alkali-treated Prosopis juliflora fibers. Int. J. Polym. Anal. Charact. 2014, 19, 309-317. [CrossRef] 
19. Vignesh, V.; Balaji, A.; Karthikeyan, M. Extraction and characterization of new cellulosic fibers from Indian mallow stem: An exploratory investigation. Int. J. Polym. Anal. Charact. 2016, 21, 504-512. [CrossRef]

20. Safri, S.N.A.; Sultan, M.T.H.; Jawaid, M.; Jayakrishna, K. Impact behaviour of hybrid composites for structural applications: A review. Compos. B Eng. 2018, 133, 112-121. [CrossRef]

21. Safaei, B.; Fattahi, A.; Chu, F. Finite element study on elastic transition in platelet reinforced composites. Microsyst. Technol. 2018, 24, 2663-2671. [CrossRef]

22. Lau, K.-T.; Hung, P.-Y.; Zhu, M.-H.; Hui, D. Properties of natural fibre composites for structural engineering applications. Compos. B Eng. 2018, 136, 222-233. [CrossRef]

23. Elanchezhian, C.; Ramnath, B.V.; Ramakrishnan, G.; Rajendrakumar, M.; Naveenkumar, V.; Saravanakumar, M.K. Review on mechanical properties of natural fiber composites. Mater. Today 2018, 5, 1785-1790. [CrossRef]

24. Dhanola, A.; Bisht, A.S.; Kumar, A.; Kumar, A. Influence of natural fillers on physico-mechanical properties of luffa cylindrica/ polyester composites. Mater. Today 2018, 5, 17021-17029. [CrossRef]

25. Bisen, H.B.; Hirwani, C.K.; Satankar, R.K.; Panda, S.K.; Mehar, K.; Patel, B. Numerical Study of Frequency and Deflection Responses of Natural Fiber (Luffa) Reinforced Polymer Composite and Experimental Validation. J. Nat. Fibers. 2018, 17, 505-519. [CrossRef]

26. Kiruthika, A.V. A review on physico-mechanical properties of bast fibre reinforced polymer composites. J. Build. Eng. 2017, 9, 91-99. [CrossRef]

27. Chen, Y.; Su, N.; Zhang, K.; Zhu, S.; Zhao, L.; Fang, F.; Ren, L.; Guo, Y. In-Depth Analysis of the Structure and Properties of Two Varieties of Natural Luffa Sponge Fibers. Materials 2017, 10, 479. [CrossRef]

28. Chandramohan, D.; Presin Kumar, A.J. Experimental data on the properties of natural fiber particle reinforced polymer composite material. Data Brief 2017, 13, 460-468. [CrossRef]

29. Jauhari, N.; Mishra, R.; Thakur, H. Natural fibre reinforced composite laminates-A review. Mater. Today 2015, 2, 2868-2877. [CrossRef]

30. Yan, L.; Chouw, N.; Jayaraman, K. Flax fibre and its composites-A review. Compos. B Eng. 2014, 56, $296-317$. [CrossRef]

31. Węcławski, B.T.; Fan, M.; Hui, D. Compressive behaviour of natural fibre composite. Compos. B Eng. 2014, 67, 183-191. [CrossRef]

32. Sathishkumar, T.P.; Navaneethakrishnan, P.; Shankar, S.; Rajasekar, R.; Rajini, N. Characterization of natural fiber and composites-A review. J. Reinf. Plast. Compos. 2013, 32, 1457-1476. [CrossRef]

33. Nguong, C.; Lee, S.; Sujan, D. A review on natural fibre reinforced polymer composites. Proc. World Acad. Sci. Eng. Technol. 2013, 7, 52-59.

34. Koronis, G.; Silva, A.; Fontul, M. Green composites: A review of adequate materials for automotive applications. Compos. B Eng. 2013, 44, 120-127. [CrossRef]

35. AL-Oqla, F.M.; Alothman, O.Y.; Jawaid, M.; Sapuan, S.; Es-Saheb, M. Processing and properties of date palm fibers and its composites. In Biomass Bioenergy; Springer: Berlin/Heidelberg, Germany, 2014; pp. 1-25.

36. Jawaid, M.; Khalil, H.A. Cellulosic/synthetic fibre reinforced polymer hybrid composites: A review. Carbohydr. Polym. 2011, 86, 1-18. [CrossRef]

37. Ho, M.-p.; Wang, H.; Lee, J.-H.; Ho, C.-k.; Lau, K.-t.; Leng, J.; Hui, D. Critical factors on manufacturing processes of natural fibre composites. Compos. B Eng. 2012, 43, 3549-3562. [CrossRef]

38. Bajpai, P.K.; Singh, I.; Madaan, J. Joining of natural fiber reinforced composites using microwave energy: Experimental and finite element study. Mater. Des. 2012, 35, 596-602. [CrossRef]

39. Rokbi, M.; Osmani, H.; Imad, A.; Benseddiq, N. Effect of Chemical treatment on Flexure Properties of Natural Fiber-reinforced Polyester Composite. Procedia Eng. 2011, 10, 2092-2097. [CrossRef]

40. Ku, H.; Wang, H.; Pattarachaiyakoop, N.; Trada, M. A review on the tensile properties of natural fiber reinforced polymer composites. Compos. B Eng. 2011, 42, 856-873. [CrossRef]

41. Alves, C.; Silva, A.; Reis, L.; Freitas, M.; Rodrigues, L.; Alves, D. Ecodesign of automotive components making use of natural jute fiber composites. J. Clean. Prod. 2010, 18, 313-327. [CrossRef]

42. Silva, G.; Kim, S.; Aguilar, R.; Nakamatsu, J. Natural fibers as reinforcement additives for geopolymers-A review of potential eco-friendly applications to the construction industry. SMET 2020, 23, e00132. [CrossRef]

43. Dawit, J.B.; Regassa, Y.; Lemu, H.G. Property characterization of acacia tortilis for natural fiber reinforced polymer composite. Results Mater. 2020, 5, 100054. [CrossRef] 
44. Jino, R.; Pugazhenthi, R.; Ashok, K.G.; Ilango, T.; Chakravarthy, P.R.K. Enhancement of Mechanical Properties of Luffa Fiber/Epoxy Composite Using B4C. J. Adv. Microsc. Res. 2017, 12, 89-91. [CrossRef]

45. Ekici, B.; Kentli, A.; Küçük, H. Improving Sound Absorption Property of Polyurethane Foams by Adding Tea-Leaf Fibers. Arch. Acoust. 2012, 37, 515-520. [CrossRef]

46. Shen, J.; Min Xie, Y.; Huang, X.; Zhou, S.; Ruan, D. Mechanical properties of luffa sponge. J. Mech. Behav. Biomed. Mater. 2012, 15, 141-152. [CrossRef]

47. Chen, Q.; Shi, Q.; Gorb, S.N.; Li, Z. A multiscale study on the structural and mechanical properties of the luffa sponge from Luffa cylindrica plant. J. Biomech. 2014, 47, 1332-1339. [CrossRef]

48. Sinnott, E.W.; Bloch, R. Development of the fibrous net in the fruit of various races of Luffa cylindrica. Bot. Gaz. 1943, 105, 90-99. [CrossRef]

49. Sabarinathan, P.; Rajkumar, K.; Gnanavelbabu, A. Investigation of mechanical properties of Luffa cylindrical and flax reinforced hybrid polymer composite. J. Adv. Eng. Res. 2016, 3, 124-127.

50. Saw, S.K.; Purwar, R.; Nandy, S.; Ghose, J.; Sarkhel, G. Fabrication, characterization, and evaluation of luffa cylindrica fiber reinforced epoxy composites. BioResources 2013, 8, 4805-4826. [CrossRef]

51. Mohanta, N.; Acharya, S.K. Fiber surface treatment: Its effect on structural, thermal, and mechanical properties of Luffa cylindrica fiber and its composite. J. Compos. Mater. 2016, 50, 3117-3131. [CrossRef]

52. Porterfield, W. Loofah-The sponge gourd. Econ. Bot. 1955, 9, 211-223. [CrossRef]

53. Ray, D.; Sarkar, B.K.; Rana, A.; Bose, N.R. Effect of alkali treated jute fibres on composite properties. Bull. Mater. Sci. 2001, 24, 129-135. [CrossRef]

54. Jino, R.; Sriraman, M.; Arthika, B.; Ashok, K. Studies on mechanical properties of luffa acutangula/lignite fly ash reinforced composites. Int. J. Eng. Technol. 2018, 7, 251-254. [CrossRef]

55. Chen, Y.; Su, N.; Zhang, K.; Zhu, S.; Zhu, Z.; Qin, W.; Yang, Y.; Shi, Y.; Fan, S.; Wang, Z.; et al. Effect of fiber surface treatment on structure, moisture absorption and mechanical properties of luffa sponge fiber bundles. Ind. Crop. Prod. 2018, 123, 341-352. [CrossRef]

56. Thangaraju, R.; Aravindakumar, A. Experimental study on the characteristics of surface treated luffa fiber composites. Int. J. Chem. Pharm. Rev. Res. 2016, 9, 646-651.

57. Parida, C.; Dash, S.K.; Das, S.C. Effect of Fiber Treatment and Fiber Loading on Mechanical Properties of Luffa-Resorcinol Composites. Indian J. Eng. Mater. Sci. 2015, 2015, 1-6. [CrossRef]

58. Parida, C.; Dash, S.K.; Chaterjee, P. Mechanical properties of injection molded poly (lactic) Acid-Luffa fiber composites. SNL 2015, 5, 65. [CrossRef]

59. Anbukarasi, K.; Kalaiselvam, S. Study of effect of fibre volume and dimension on mechanical, thermal, an water absorption behaviour of luffa reinforced epoxy composites. Mater. Des 2015, 66, 321-330. [CrossRef]

60. Tanobe, V.; Flores-Sahagun, T.; Amico, S.; Muniz, G.; Satyanarayana, K. Sponge Gourd (Luffa Cylindrica) Reinforced Polyester Composites: Preparation and Properties. Def. Sci. J. 2014, 64, 273-280. [CrossRef]

61. Srinivasan, C.; Sathish, S.; Vignesh, K. Mechanical properties of chemically treated Luffa Aegyptiaca fiber reinforced epoxy matrix composites. Int. J. Sci. Res. Manag. 2014, 2, 1515-1524.

62. Panneerdhass, R.; Gnanavelbabu, A.; Rajkumar, K. Mechanical Properties of Luffa Fiber and Ground nut Reinforced Epoxy Polymer Hybrid Composites. Procedia Eng. 2014, 97, 2042-2051. [CrossRef]

63. Panneerdhass, R.; Baskaran, R.; Rajkumar, K.; Gnanavelbabu, A. Mechanical Properties of Chopped Randomly Oriented Epoxy-Luffa Fiber Reinforced Polymer Composite. Appl. Mech. Mater. 2014, 591, 103-107. [CrossRef]

64. Botaro, V.R.; Novack, K.M.; Siqueira, É.J. Dynamic mechanical behavior of vinylester matrix composites reinforced by Luffa cylindrica modified fibers. J. Appl. Polym. Sci. 2012, 124, 1967-1975. [CrossRef]

65. Ghali, L.H.; Aloui, M.; Zidi, M.; Daly, H.B.; Msahli, S.; Sakli, F. Effect of chemical modification of luffa cylindrica fibers on the mechanical and hygrothermal behaviours of polyester/luffa composites. BioResources 2011, 6, 3836-3849.

66. Ghali, L.; Msahli, S.; Zidi, M.; Sakli, F. Effects of Fiber Weight Ratio, Structure and Fiber Modification onto Flexural Properties of Luffa-Polyester Composites. Adv. Mater. Phys. Chem. 2011, 1, 78-85. [CrossRef]

67. Ghali, L.; Msahli, S.; Zidi, M.; Sakli, F. Effect of pre-treatment of Luffa fibres on the structural properties. Mater. Lett. 2009, 63, 61-63. [CrossRef]

68. Demir, H.; Atikler, U.; Balköse, D.; Tihmınlığlu, F. The effect of fiber surface treatments on the tensile and water sorption properties of polypropylene-luffa fiber composites. Compos. Part A Appl. Sci. Manuf. 2006, 37, 447-456. [CrossRef] 
69. Tanobe, V.O.A.; Sydenstricker, T.H.D.; Munaro, M.; Amico, S.C. A comprehensive characterization of chemically treated Brazilian sponge-gourds (Luffa cylindrica). Polym. Test. 2005, 24, 474-482. [CrossRef]

70. Boynard, C.; Monteiro, S.; d'Almeida, J. Aspects of alkali treatment of sponge gourd (Luffa cylindrica) fibers on the flexural properties of polyester matrix composites. J. Appl. Polym. Sci. 2003, 87, 1927-1932. [CrossRef]

71. Kalusuraman, G.; Siva, I.; Munde, Y.; Selvan, C.P.; Kumar, S.A.; Amico, S.C. Dynamic-mechanical properties as a function of luffa fibre content and adhesion in a polyester composite. Polym. Test. 2020, 87, 106538. [CrossRef]

72. Dharmalingam, S.; Meenakshisundaram, O.; Kugarajah, V. Effect of Degree of Silanization of Luffa on the properties of Luffa-Epoxy Composites. Colloids Surf. A Physicochem. Eng. Aspects 2020, 603, 125273. [CrossRef]

73. Ashok, K.; Kalaichelvan, K.; Damodaran, A. Effect of Nano Fillers on Mechanical Properties of Luffa Fiber Epoxy Composites. J. Nat. Fibers. 2020, 1-18. [CrossRef]

74. Mohana Krishnudu, D.; Sreeramulu, D.; Reddy, P.V.; Rajendra Prasad, P. Influence of Filler on Mechanical and Di-electric Properties of Coir and Luffa Cylindrica Fiber Reinforced Epoxy Hybrid Composites. J. Nat. Fibers. 2020, 17, 1-10. [CrossRef]

75. Chakrabarti, D.; Islam, M.S.; Jubair, K.; Sarker, M.R.H. Effect of Chemical Treatment on the Mechanical Properties of Luffa Fiber Reinforced Epoxy Composite. J. Eng. Adv. 2020, 1, 37-42. [CrossRef]

76. Yang, X.; Wang, X.; Zhao, Y.; Xu, L.; Wang, T.; Zhang, X. Preparation of recyclable BiOI/luffa fiber composite and its highly efficient visible light photocatalytic properties. J. Clean. Prod. 2018, 200, 945-953. [CrossRef]

77. Shen, J.; Xie, Y.M.; Huang, X.; Zhou, S.; Ruan, D. Behaviour of luffa sponge material under dynamic loading. Int. J. Impact Eng. 2013, 57, 17-26. [CrossRef]

78. Parida, C.; Das, S.C.; Dash, S.K. Mechanical Analysis of Bio Nanocomposite Prepared from Luffa cylindrica. Procedia Chem. 2012, 4, 53-59. [CrossRef]

79. Pires, C.; Motta, L.A.d.C.; Ferreira, R.A.d.R.; Caixeta, C.d.O.; Savastano, H. Thermomechanical and Thermo-hydro-mechanical Treatments of Luffa Cylindrical Fibers. J. Nat. Fibers. 2020, 17, 1-13. [CrossRef]

80. Kakar, A.; Jayamani, E.; Soon, K.H.; Bakri, M.K.B. Study of dielectric properties of luffa-polylactide quadratic splint composites: The effect of cyclic absorption and desorption of water. J. Vinyl. Addit. Technol. 2018, 24, 388-394. [CrossRef]

81. Al-Mobarak, T.; Mina, M.; Gafur, M. Improvement in mechanical properties of sponge-gourd fibers through different chemical treatment as demonstrated by utilization of the Weibull distribution model. J. Nat. Fibers. 2020, 17, 573-588. [CrossRef]

82. Yin, S.; Wang, H.; Li, J.; Ritchie, R.O.; Xu, J. Light but tough bio-inherited materials: Luffa sponge based nickel-plated composites. J. Mech. Behav. Biomed. 2019, 94, 10-18. [CrossRef] [PubMed]

83. Guo, Y.; Wang, L.; Chen, Y.; Luo, P.; Chen, T. Properties of luffa fiber reinforced phbv biodegradable composites. Polymers 2019, 11, 1765. [CrossRef] [PubMed]

84. Sivakandhan, C.; Balaji, R.; Loganathan, G.B.; Madan, D.; Murali, G. Investigation of mechanical behaviour on sponge/ridge gourd (Luffa aegyptiaca) natural fiber using epoxy and polyester resin. Mater. Today 2020, 22, 705-714. [CrossRef]

85. Kalusuraman, G.; Kumaran, S.T.; Siva, I.; Kumar, S.A. Cutting performance of luffa cylindrica fiber-reinforced composite by abrasive water jet. J. Test. Eval. 2020, 48, 20180330. [CrossRef]

86. Daniel-Mkpume, C.; Ugochukwu, C.; Okonkwo, E.; Fayomi, O.; Obiorah, S. Effect of Luffa cylindrica fiber and particulate on the mechanical properties of epoxy. Int. J. Adv. Manuf. Technol. 2019, 102, 3439-3444. [CrossRef]

87. Koruk, H.; Genc, G. Investigation of the acoustic properties of bio luffa fiber and composite materials. Mater. Lett. 2015, 157, 166-168. [CrossRef]

88. Mohanta, N.; Acharya, S. Tensile, flexural and interlaminar shear properties of Luffa cylindrica fibre reinforced epoxy composites. Int. J. Macromol. Sci 2013, 3, 6-10.

89. Genc, G.; Körük, H. Investigation of the vibro-acoustic behaviors of luffa bio composites and assessment of their use for practical applications. In Proceedings of the 23rd International Congress on Sound and Vibration 2016, ICSV 2016, Athens, Greece, 10-14 July 2016; pp. 1-8. [CrossRef]

90. Mohanta, N.; Acharya, S.K. Mechanical and tribological performance of Luffa cylindrica fibre-reinforced epoxy composite. BioResources 2015, 10, 8364-8377. [CrossRef] 
91. Mohanta, N.; Acharya, S.K. Investigation of mechanical properties of luffa cylindrica fibre reinforced epoxy hybrid composite. Int. J. Eng. Sci. Technol. 2015, 7. [CrossRef]

92. Genc, G.; Sarikas, A.; Kesen, U.; Aydin, S. Luffa/Epoxy composites: Electrical properties for PCB application. IEEE Trans. Compon. Packag. Manuf. Technol. 2020, 10, 933-940. [CrossRef]

93. Saygili, Y.; Genc, G.; Sanliturk, K.Y.; Koruk, H. Investigation of the acoustic and mechanical properties of homogenous and hybrid jute and luffa bio composites. J. Nat. Fibers. 2020, 17, 1-9. [CrossRef]

94. Boynard, C.A.; D'Almeida, J.R.M. Morphological Characterization and Mechanical Behavior of Sponge Gourd (Luffa Cylindrica)-Polyester Composite Materials. Polym. Plast. Technol. Eng. 2000, 39, 489-499. [CrossRef]

95. Boynard, C.; d'Almeida, J. Water absorption by sponge gourd (luffa cylindrica)-polyester composite materials. J. Mater. Sci. Lett. 1999, 18, 1789-1791. [CrossRef]

96. NagarajaGanesh, B.; Muralikannan, R. Extraction and characterization of lignocellulosic fibers fromLuffa cylindricafruit. Int. J. Polym. Anal. Charact. 2016, 21, 259-266. [CrossRef]

97. Akgül, M.; Korkut, S.; Çamlıbel, O.; Ayata, Ü. Some chemical properties of luffa and its suitability for medium density fiberboard (MDF) production. BioResources 2013, 8, 1709-1717. [CrossRef]

98. Escocio, V.A.; Visconte, L.L.Y.; Cavalcante, A.d.P.; Furtado, A.M.S.; Pacheco, E.B.A.V. Study of mechanical and morphological properties of bio-based polyethylene (HDPE) and sponge-gourds (Luffa-cylindrica) agroresidue composites. In AIP Conference Proceedings; AIP: Cleveland, OH, USA, 2015; p. 060012. [CrossRef]

99. Jamaluddin, J.; Firouzi, A.; Islam, M.; Yahaya, A. Effects of luffa and glass fibers in polyurethane-based ternary sandwich composites for building materials. SN Appl. Sci. 2020, 2, 1-10. [CrossRef]

100. Alshaaer, M.; Mallouh, S.A.; Al-Kafawein, J.a.; Al-Faiyz, Y.; Fahmy, T.; Kallel, A.; Rocha, F. Fabrication, microstructural and mechanical characterization of Luffa Cylindrical Fibre-Reinforced geopolymer composite. Appl. Clay Sci. 2017, 143, 125-133. [CrossRef]

101. Kaewtatip, K.; Thongmee, J. Studies on the structure and properties of thermoplastic starch/luffa fiber composites. Mater. Des. 2012, 40, 314-318. [CrossRef]

102. Chen, Y.; Yuan, F.; Guo, Y.; Hu, D.; Zhu, Z.; Zhang, K.; Zhu, S. A novel mattress filling material comprising of luffa fibers and EVA resin. Ind. Crops Prod. 2018, 124, 213-215. [CrossRef]

103. Quadri, A.I.; Alabi, O. Assessment of Sponge Gourd (Luffa Aegyptical) Fiber as a Polymer Reinforcement in Concrete. J. Civ. Eng. Mater. Appl. 2020, 4, 125-132.

104. NagarajaGanesh, B.; Ganeshan, P.; Ramshankar, P.; Raja, K. Assessment of natural cellulosic fibers derived from Senna auriculata for making light weight industrial biocomposites. Ind. Crops Prod. 2019, 139, 111546. [CrossRef]

105. Bhingare, N.H.; Prakash, S.; Jatti, V.S. A review on natural and waste material composite as acoustic material. Polym. Test. 2019, 80, 106142. [CrossRef]

106. Mittal, V.; Saini, R.; Sinha, S. Natural fiber-mediated epoxy composites-a review. Compos. B Eng. 2016, 99, 425-435. [CrossRef]

107. Gurunathan, T.; Mohanty, S.; Nayak, S.K. A review of the recent developments in biocomposites based on natural fibres and their application perspectives. Compos. Part A Appl. Sci. Manuf. 2015, 77, 1-25. [CrossRef]

108. Al-Oqla, F.M.; Sapuan, S. Natural fiber reinforced polymer composites in industrial applications: Feasibility of date palm fibers for sustainable automotive industry. J. Clean. Prod. 2014, 66, 347-354. [CrossRef]

109. Yang, Q.; Zhai, Y.; Li, X.; Li, H. Synthesis of Fe3O4/Pr-BiOCl/Luffa composites with enhanced visible light photoactivity for organic dyes degradation. Mater. Res. Bull. 2018, 106, 409-417. [CrossRef]

110. Satankar, R.K.; Sharma, N.; Panda, S.K.; Mohapatra, S.S. Experimental and simulation study of eigen frequency responses of Luffa cylindrica sponge fibre polymer composite. Mater. Today 2020. [CrossRef]

111. Shih, Y.-J.; Dong, C.-D.; Huang, Y.-H.; Huang, C. Electro-sorption of ammonium ion onto nickel foam supported highly microporous activated carbon prepared from agricultural residues (dried Luffa cylindrica). Sci. Total Environ. 2019, 673, 296-305. [CrossRef]

112. Wu, Y.; Hu, W.; Xie, R.; Liu, X.; Yang, D.; Chen, P.; Zhang, J.; Zhang, F. Composite of nano-goethite and natural organic luffa sponge as template: Synergy of high efficiency adsorption and visible-light photocatalysis. Inorg. Chem. Commun. 2018, 98, 115-119. [CrossRef]

113. Sreeramulu, D.; Ramesh, N. Synthesis, characterization, and properties of epoxy filled Luffa cylindrica reinforced composites. Mater. Today 2018, 5, 6518-6524. 
114. Saw, S.K. Effect of stacking patterns on morphological and mechanical properties of luffa/coir hybrid fiber-reinforced epoxy composite laminates. In Hybrid Polymer Composite Materials; Elsevier: Amsterdam, The Netherlands, 2017; pp. 313-333.

115. Mohanta, N.; Acharya, S.K. Effect of alkali treatment on the flexural properties of a Luffa cylindrica-reinforced epoxy composite. Sci. Eng. Compos. Mater. 2018, 25, 85-93. [CrossRef]

116. Malkapuram, R.; Kumar, V.; Negi, Y.S. Recent development in natural fiber reinforced polypropylene composites. J. Reinf. Plast. Compos. 2009, 28, 1169-1189. [CrossRef]

117. O'donnell, A.; Dweib, M.; Wool, R. Natural fiber composites with plant oil-based resin. Compos. Sci. Technol. 2004, 64, 1135-1145. [CrossRef]

118. Wang, Z.; Ma, H.; Chu, B.; Hsiao, B.S. Super-hydrophobic modification of porous natural polymer "luffa sponge" for oil absorption. Polymer 2017, 126, 470-476. [CrossRef]

119. Saraiva, A.B.; Pacheco, E.B.; Gomes, G.M.; Visconte, L.L.; Bernardo, C.; Simoes, C.L.; Soares, A.G. Comparative lifecycle assessment of mango packaging made from a polyethylene/natural fiber-composite and from cardboard material. J. Clean. Prod. 2016, 139, 1168-1180. [CrossRef]

120. Kocak, D.; Mistik, S.; Akalin, M.; Merdan, N. The use of Luffa cylindrica fibres as reinforcements in composites. In Biofiber Reinforcements in Composite Materials; Elsevier: Amsterdam, The Netherlands, 2015; pp. 689-699.

121. Premalatha, N.; Saravanakumar, S.; Sanjay, M.; Siengchin, S.; Khan, A. Structural and thermal properties of chemically modified Luffa Cylindrica fibers. J. Nat. Fibers. 2019, 16, 1-7. [CrossRef]

122. Bera, T.; Mohanta, N.; Prakash, V.; Pradhan, S.; Acharya, S.K. Moisture absorption and thickness swelling behaviour of luffa fibre/epoxy composite. J. Reinf. Plast. Compos. 2019, 38, 923-937. [CrossRef]

123. Sewda, K.; Maiti, S. Mechanical properties of teak wood flour-reinforced HDPE composites. J. Appl. Polym. Sci. 2009, 112, 1826-1834. [CrossRef]

124. Samanta, B.; Maity, T.; Dalai, S.; Banthia, A. Mechanical properties of modified epoxy: Effect of chain length. Pigment Resin Technol. 2006, 35, 216-223. [CrossRef]

125. Krishnudu, D.M.; Sreeramulu, D.; Reddy, P.V. A study of filler content influence on dynamic mechanical and thermal characteristics of coir and luffa cylindrica reinforced hybrid composites. Constr. Build Mater. 2020, 251, 119040. [CrossRef]

126. Chen, Y.; Yuan, F.; Su, Q.; Yu, C.; Zhang, K.; Luo, P.; Hu, D.; Guo, Y. A novel sound absorbing material comprising discarded luffa scraps and polyester fibers. J. Clean. Prod. 2020, 245, 118917. [CrossRef]

127. Koruk, H.; Genç, G. Acoustic and mechanical properties of luffa fiber-reinforced biocomposites. In Mechanical and Physical Testing of Biocomposites, Fibre-Reinforced Composites and Hybrid Composites; Elsevier: Amsterdam, The Netherlands, 2019; pp. 325-341.

128. Keskin, O.; Yilmaz, S. Parameters affecting sound absorption in fiber composites: A case study for Luffa Cylindrica. In IDES'19 International Design and Engineering Symposium: Sustainability, Innovation, Production; Izmir Democracy University: Izmir, Turkey, 2019.

129. Taiwo, E.M.; Yahya, K.; Haron, Z. Potential of using natural fiber for building acoustic absorber: A review. J. Phys. Conf. Ser. 2019, 1262, 012017. [CrossRef]

130. Alhijazi, M.; Zeeshan, Q.; Qin, Z.; Safaei, B.; Asmael, M. Finite element analysis of natural fibers composites: A review. Nanotechnol. Rev. 2020, 9, 853-875. [CrossRef]

131. Jeyapragash, R.; Srinivasan, V.; Sathiyamurthy, S. Mechanical properties of natural fiber/particulate reinforced epoxy composites-A review of the literature. Mater. Today 2020, 22, 1223-1227. [CrossRef]

132. Wang, X.; Shen, J.; Zuo, Z.H.; Huang, X.; Zhou, S.; Xie, Y.M. Numerical investigation of compressive behaviour of luffa-filled tubes. Compos. B Eng. 2015, 73, 149-157. [CrossRef]

133. Ashok, K.; Kalaichelvan, K.; Elango, V.; Damodaran, A.; Gopinath, B.; Raju, M. Mechanical and morphological properties of luffa/carbon fiber reinforced hybrid composites. Mater. Today 2020. [CrossRef]

134. Mani, P.; Dellibabu, G.; Anilbasha, K.; Anbukarsi, K. Tensile and flexural properties of Luffa fiber reinforced composite material. Int. J. Eng. Res. Technol. 2014, 3, 1882-1885.

135. Paglicawan, M.A.; Cabillon, M.S.; Cerbito, R.P.; Santos, E.O. Loofah fiber as reinforcement material for composite. Philipp. J. Sci. 2005, 134, 113.

136. Khan, M.A.; Hassan, M.M.; Drzal, L.T. Effect of 2-hydroxyethyl methacrylate (HEMA) on the mechanical and thermal properties of jute-polycarbonate composite. Compos. Part A Appl. Sci. Manuf. 2005, 36, 71-81. [CrossRef] 
137. White, J.E.; Catallo, W.J.; Legendre, B.L. Biomass pyrolysis kinetics: A comparative critical review with relevant agricultural residue case studies. J. Anal. Appl. Pyrolysis 2011, 91, 1-33. [CrossRef]

138. Putson, C.; Jaaoh, D.; Muensit, N. Interface polarization effect on dielectric and electrical properties of polyurethane (PU)/polyaniline (PANI) polymer composites. Adv. Mater. Res. 2013, 770, 275-278. [CrossRef]

139. Karthi, N.; Kumaresan, K.; Sathish, S.; Gokulkumar, S.; Prabhu, L.; Vigneshkumar, N. An overview: Natural fiber reinforced hybrid composites, chemical treatments and application areas. Mater. Today 2020, 27, 2828-2834. [CrossRef]

140. Sreekala, M.; George, J.; Kumaran, M.; Thomas, S. The mechanical performance of hybrid phenol-formaldehydebased composites reinforced with glass and oil palm fibres. Compos. Sci. Technol. 2002, 62, 339-353. [CrossRef]

141. Arrakhiz, F.; Hamou, K.B.; Erchiqui, F.; Hammiche, D.; Kaddami, H. Development and characterization of hybrid composite laminate based on luffa and glass fibers. Mater. Today 2020. [CrossRef]

142. Patel, V.K.; Dhanola, A. Influence of $\mathrm{CaCO} 3, \mathrm{Al} 2 \mathrm{O} 3$, and $\mathrm{TiO} 2$ microfillers on physico-mechanical properties of Luffa cylindrica/polyester composites. Eng. Sci. Technol. Int. J. 2016, 19, 676-683. [CrossRef]

143. Lai, S.-M.; Kao, Y.-H.; Liu, Y.-K.; Chiu, F.-C. Preparation and properties of luffa fiber-and kenaf fiber-filled poly (butylene succinate-co-lactate)/starch blend-based biocomposites. Polym. Test. 2016, 50, 191-199. [CrossRef]

(C) 2020 by the authors. Licensee MDPI, Basel, Switzerland. This article is an open access article distributed under the terms and conditions of the Creative Commons Attribution (CC BY) license (http://creativecommons.org/licenses/by/4.0/). 